\title{
An Assessment of Hydropower Environmental Mitigation Costs
}

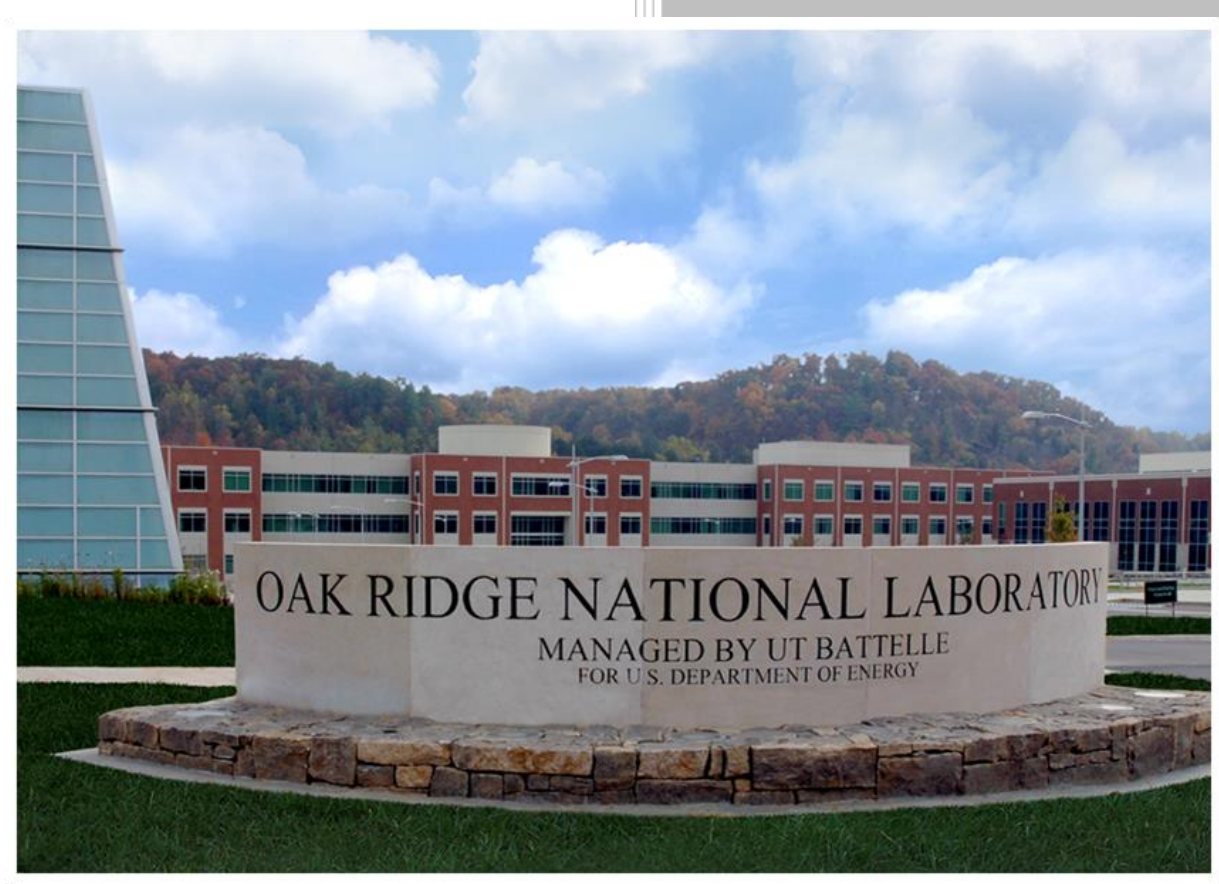

Gbadebo Oladosu Joseph Werble William Tingen Adam Witt Miles Mobley Patrick O'Connor

Final

August 2019 


\title{
DOCUMENT AVAILABILITY
}

Reports produced after January 1, 1996, are generally available free via US Department of Energy (DOE) SciTech Connect.

Website www.osti.gov

Reports produced before January 1, 1996, may be purchased by members of the public from the following source:

\author{
National Technical Information Service \\ 5285 Port Royal Road \\ Springfield, VA 22161 \\ Telephone 703-605-6000 (1-800-553-6847) \\ TDD 703-487-4639 \\ Fax 703-605-6900 \\ E-mail info@ntis.gov \\ Website http://classic.ntis.gov/
}

Reports are available to DOE employees, DOE contractors, Energy Technology Data Exchange representatives, and International Nuclear Information System representatives from the following source:

Office of Scientific and Technical Information

PO Box 62

Oak Ridge, TN 37831

Telephone 865-576-8401

Fax 865-576-5728

E-mail reports@osti.gov

Website http://www.osti.gov/contact.html

This report was prepared as an account of work sponsored by an agency of the United States Government. Neither the United States Government nor any agency thereof, nor any of their employees, makes any warranty, express or implied, or assumes any legal liability or responsibility for the accuracy, completeness, or usefulness of any information, apparatus, product, or process disclosed, or represents that its use would not infringe privately owned rights. Reference herein to any specific commercial product, process, or service by trade name, trademark, manufacturer, or otherwise, does not necessarily constitute or imply its endorsement, recommendation, or favoring by the United States Government or any agency thereof. The views and opinions of authors expressed herein do not necessarily state or reflect those of the United States Government or any agency thereof. 
Environmental Sciences Division

\title{
An Assessment of Hydropower Environmental Mitigation Costs
}

\author{
Authored by: \\ Gbadebo Oladosu, Joseph Werble, William Tingen, Adam Witt, Miles Mobley, Patrick O’Connor
}

Date Published: August 2019

\author{
Prepared by \\ OAK RIDGE NATIONAL LABORATORY \\ Oak Ridge, TN 37831-6283 \\ managed by \\ UT-BATTELLE, LLC \\ for the \\ US DEPARTMENT OF ENERGY \\ under contract DE-AC05-00OR22725
}





\section{CONTENTS}

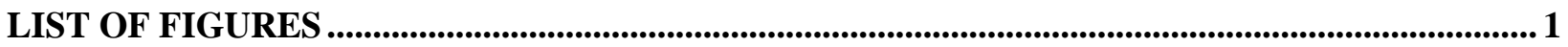

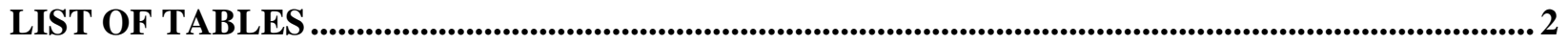

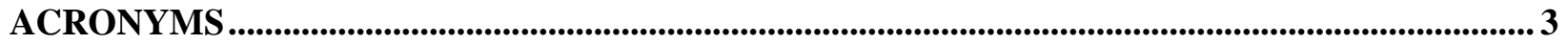

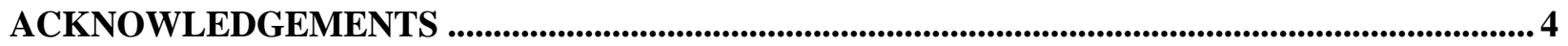

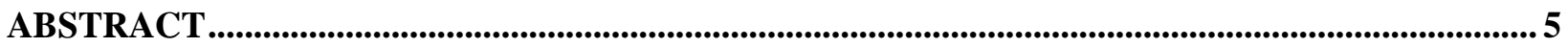

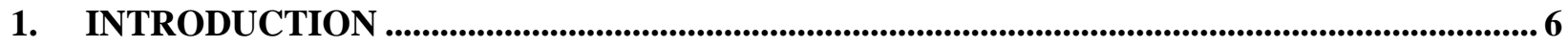

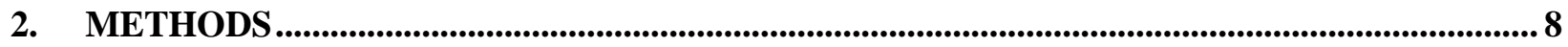

2.1 Existing Studies of Hydropower Environmental Mitigation Measures ................................... 8

2.2 Environmental Mitigation Cost Database Development..................................................... 9

2.3 Hydropower Project Types .......................................................................................... 10

2.3.1 Relicensed Conventional Hydropower Dams …........................................................... 10

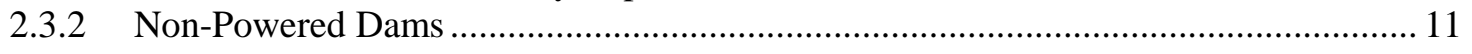

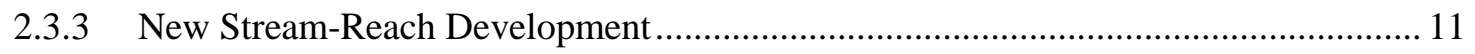

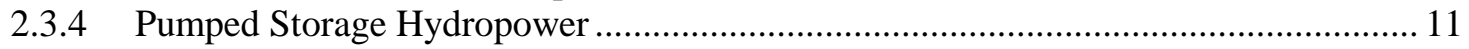

2.4 Environmental Mitigation Data Classification Scheme …................................................... 12

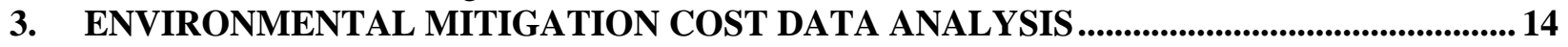

3.1 Overview of PM\&E Capital and O\&M Costs...................................................................... 14

3.2 PM\&E Costs for Relicensed Conventional Hydropower Dams …......................................... 16

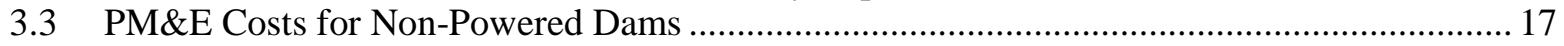

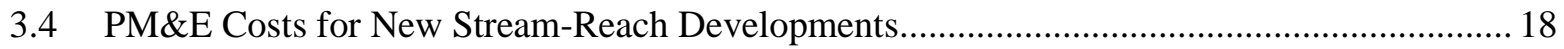

3.5 PM\&E Costs for Relicensed Pumped Storage Hydropower ................................................ 20

3.6 PM\&E Costs for New Pumped Storage Hydropower.......................................................... 21

3.7 Levelized Costs of PM\&E Across RCHD, NPD, and NSD Projects................................... 23

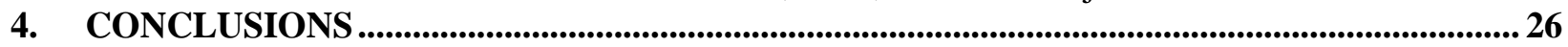

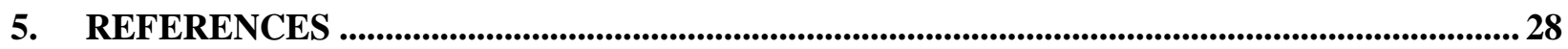

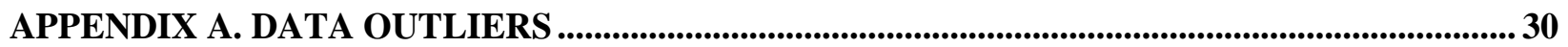




\section{LIST OF FIGURES}

Figure 1: Example of a conservative hydropower development timeline for a project licensed by FERC. Source: Adapted from Meier et al. (2010)........................................... 7

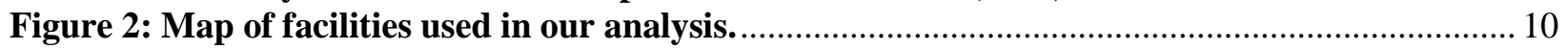

Figure 3: Tiered classification scheme for PM\&E measures...................................................... 12

Figure 4: Capital PM\&E Costs by Year, Installed Capacity, and PM\&E Measure Count for all 181 projects in our dataset.

Figure 5: O\&M PM\&E Costs by Year, Installed Capacity, and PM\&E Measure Count for all 181 projects in our dataset.

Figure 6: Capital and O\&M PM\&E Costs for the 103 Relicensed Conventional projects across the 11 Mitigation Categories.

Figure 7: Capital and PM\&E Costs for the 57 NPD projects across the 11 Mitigation Categories.

Figure 8: Capital and O\&M PM\&E Costs for the 11 NSD Projects across the 10 Mitigation Categories. Note that there were no Project Operations measures for any of the 11 projects.

Figure 9: Capital and O\&M PM\&E Costs for the 6 Relicensed PSH projects across the 11 Mitigation Categories.

Figure 10: Capital and O\&M PM\&E Costs for the 4 New PSH projects across the 11 Mitigation Categories.

Figure 11: PM\&E LCOE Estimates for the 57 NPD projects between 2004 and 2016. The dots represent the percentage of PM\&E LCOE in Total Project LCOE.

Figure 12: PM\&E LCOE Estimates for the 11 NSD projects between 2011 and 2017. The dots represent the percentage of PM\&E LCOE in Total Project LCOE.

Figure 13: PM\&E LCOE Estimates for the 103 Relicensed Conventional projects between 1996 and 2017. Not enough data was available to determine the proportion of PM\&E in Total Project LCOE. 


\section{LIST OF TABLES}

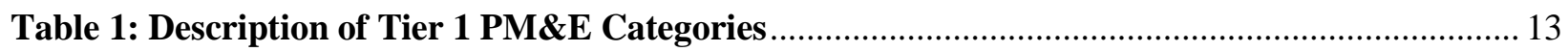




\section{ACRONYMS}

$\begin{array}{ll}\text { CWA } & \text { Clean Water Act } \\ \text { EA } & \text { Environmental Assessment } \\ \text { EIS } & \text { Environmental Impact Statement } \\ \text { ESA } & \text { Endangered Species Act } \\ \text { FERC } & \text { Federal Energy Regulatory Commission } \\ \text { FPA } & \text { Federal Power Act } \\ \text { IQR } & \text { Interquartile Range } \\ \text { LCOE } & \text { Levelized Cost of Energy } \\ \text { NEPA } & \text { National Environmental Policy Act } \\ \text { NGO } & \text { Non-Governmental Organization } \\ \text { NMFS } & \text { National Marine Fisheries Service } \\ \text { NPD } & \text { Non-Powered Dams } \\ \text { NPSH } & \text { New Pumped Storage Hydropower } \\ \text { NSD } & \text { New Stream-Reach Developments } \\ \text { ORNL } & \text { Oak Ridge National Laboratory } \\ \text { O\&M } & \text { Operations and Maintenance } \\ \text { pLCOE } & \text { Protection, Mitigation, and Enhancement Levelized Cost of Energy } \\ \text { PM\&E } & \text { Protection, Mitigation, and Enhancement } \\ \text { PSH } & \text { Pumped Storage Hydropower } \\ \text { RCHD } & \text { Relicensed Conventional Hydropower Dams } \\ \text { RPSH } & \text { Relicensed Pumped Storage Hydropower } \\ \text { USFWS } & \text { U.S. Fish and Wildlife Service } \\ \text { WDNR } & \text { Wisconsin Department of Natural Resources } \\ \text { U.S. } & \text { United States }\end{array}$




\section{ACKNOWLEDGEMENTS}

\section{U.S. Department of Energy, Water Power Technologies Office}

The authors would like to acknowledge and express their appreciation to the U.S. Department of Energy Water Power Technologies Office for overseeing and funding this effort.

\section{Oak Ridge National Laboratory}

The following individuals from Oak Ridge National Laboratory provided technical review support for this report.

- Colin Sasthav

- Scott DeNeale 


\begin{abstract}
This report provides an assessment of environmental mitigation costs for hydropower projects across the United States (U.S.) based on data extracted from Environmental Assessments (EA) submitted to the Federal Energy Regulatory Commission (FERC). EAs are required by the Federal Power Act (FPA) for hydropower license and relicense applications to weigh the "power" and "non-power" (i.e.

environmental) benefits of their development and operation. For this analysis, we collected data from 184 EA documents reviewed by FERC between 1996 and 2018, and created a database of environmental protection, mitigation, and enhancement (PM\&E) measures with their associated economic information. The data cover two hydropower relicense categories - 103 Relicensed Conventional Hydropower Dams (RCHD) and 6 Relicensed Pumped Storage Hydropower (RPSH) projects - and three new development categories - 57 hydropower retrofits at Non-Powered Dams (NPD), 11 New Stream-Reach Development (NSD) projects and 6 Pumped Storage Hydropower (NPSH) projects. For the analysis, we classify the $\mathrm{PM} \& \mathrm{E}$ measures into 11 Tier 1 categories. We evaluated capital and operations \& maintenance (O\&M) costs of PM\&E measures on a $\$ / \mathrm{kW}$ basis by project type and mitigation category, as well as their share in the total project levelized cost of energy (LCOE). Below are the major findings of our analysis:
\end{abstract}

- Capital and O\&M PM\&E costs, on a $\$ / \mathrm{kW}$ basis, are generally higher for RCHD projects, partially due to new environmental standards that were not extant when they were originally licensed decades earlier. In addition, some RCHD projects in our database have small installed capacities, raising costs on a per $\mathrm{kW}$ basis, and others have no PM\&E costs for certain mitigation categories.

- Capital and O\&M PM\&E costs, on a $\$ / \mathrm{kW}$ basis, are generally lower for RPSH and NPSH projects. Yet, total PM\&E costs for these two project types are among the highest due to their much larger installed capacities relative to other types. Additionally, NPSH projects use the closed-loop configuration i.e. they are not continuously connected to a natural water body, and hence, have fewer environmental impacts. In contrast, RPSH projects are open-loop (continuously connected to a natural water body), which has more environmental impacts.

- Mitigation measures associated with Geologic Resources, Terrestrial Resources, Project Operations, Recreation Resources, and Aquatic Species generally have the highest median capital expenditures per $\mathrm{kW}$, with slight variations, across all project types. These mitigation measures are usually involved with the initial planning and construction stages, leading to high upfront costs related to studies, excavation, and physical facility components. O\&M cost per $\mathrm{kW}$ are low across all project types, signifying that O\&M is rarely a significant burden.

- LCOE estimates for PM\&E measures across NPD and NSD projects, are mostly below $\$ 20 / M W h$, with few exceptions. PM\&E measures for NPD and NSD projects typically account for $5-10 \%$ of total project LCOE, but a handful of projects are in the $20-40 \%$ range. PSH projects were excluded from the LCOE calculations since we do not have enough information on their operations. Similarly, there was not enough data to calculate the percentage of PM\&E LCOE in total project LCOE for RCHD projects.

In summary, this study found that environmental mitigation costs could hamper future NPD and NSD projects in the U.S. due to the prevalence of sites with small potential capacities (Kao et al., 2014) for which the PM\&E costs represent a larger share of total project costs. Relicensing of existing hydropower projects (RCHD) may also be constrained by newer, and stricter, environmental requirements, especially for smaller plants. However, future NPSH development can be accelerated via closed-loop configurations, which would reduce environmental impacts and hence, lower their PM\&E costs. But, for large NPSH facilities, the substantial total costs of implementing PM\&E measures may still be detrimental. Overall, our findings indicate that technologies that reduce (or cost effectively mitigate) environmental issues at hydropower sites should be a priority area for future hydropower development. 


\section{INTRODUCTION}

Hydropower plants provide clean electricity and ancillary services that support power grid stability and resilience, in addition to a variety of "non-power" benefits. Conventional dam impoundments often provide valuable services in terms of water supply, irrigation, and flood control; however, they may also adversely affect river navigability, fish and wildlife resources, and water quality, among other environmental effects. The net value of these impacts varies widely and is site-specific. As such, licensing processes have been developed in the United States and countries around the world to regulate and control the potential negative impacts of hydropower on the surrounding ecologic and human systems.

The Federal Energy Regulatory Commission (FERC), authorized under the Federal Power Act (FPA), is the primary power system regulatory authority in the U.S. (FERC, 2017; Wilkinson et al., 2017). The FPA establishes the application requirements and evaluation standards for licensing and re-licensing hydroelectric facilities and defines the authoritative boundaries between state and federal agencies (Wilkinson et al., 2017). Fish and wildlife agencies at the state and federal levels have the authority to impose conditions on the license in order to protect, mitigate, and enhance ecological resources, fish passage conditions, terrestrial and aquatic habitat requirements, and much more (Wilkinson et al., 2017). Other federal statutes such as the Endangered Species Act (ESA) and Clean Water Act (CWA) expand the authority of federal agencies and state governments in prescribing license conditions that safeguard the environment (Wilkinson et al., 2017). The ESA allows the U.S. Fish and Wildlife Service (USFWS) and National Marine Fisheries Service (NMFS) to impose any measures deemed necessary to protect endangered and threatened species and their habitats (Wilkinson et al., 2017). Under the CWA, state governments can specify conditions to ensure that operation of the proposed development does not harm their riverine and watershed resources (Wilkinson et al., 2017). Additional relevant statutes include, but are not limited to, the Coastal Zone Management Act, National Historic Preservation Act, and MagnusonStevens Fishery Conservation and Management Act. (Wilkinson et al., 2017).

Consequently, the hydropower licensing and re-licensing process is often lengthy and complex, lasting multiple years and even extending up to ten years in extreme cases. However, the licensing timeframe varies considerably depending on the project size and required type of license process. For instance, exemptions are available for two types of developments: $<10 \mathrm{MW}$ facilities on non-federal, non-powered dams (NPD) built prior to 2005 and <40 MW facilities on man-made, non-powered conduits (FERC, 2017). For all other projects, three licensing paths are available - Integrated, Traditional, or Alternative 1 - with the default being Integrated and the others requiring initial FERC approval (FERC, 2017). Regardless of which, an Environmental Assessment (EA) is required by the National Environmental Policy Act (NEPA) to weigh the "power" and "non-power" costs and benefits of the proposed development or continued operation of an existing development (Wilkinson et al., 2017). NEPA details the process to compile an EA, which generally consists of the project's purpose, list of consulted governmental and civilian stakeholders, alternative developments if applicable, and environmental impacts of the project and alternatives (FERC, 2017). Upon review of the EA, FERC can either issue a "finding of no significant impact" or determine that the environmental impacts warrant further

\footnotetext{
${ }^{1}$ According to FERC's Hydropower Licensing website (https://www.ferc.gov/industries/hydropower/geninfo/licensing/ilp.asp), the three licensing paths can be defined as:

- Integrated - streamlines communication with stakeholders early in licensing process, establishes clear timeframes for developing the license application, and allows for early submittal of licensing studies.

- Traditional - essentially is business-as-usual, involves three distinct stages of with specified objectives and timeframes to meet.

- Alternative - simplifies the initial stage of the Traditional license application process by combining the pre-filing consultation and environmental review processes.
} 
investigation, at which time an Environmental Impact Statement (EIS) must be prepared (FERC, 2017). Thus, EA documents are a major step in the licensing process, as they are the basis for FERC's determination of the need for additional studies, which can lengthen the licensing timeline. Figure 1 shows a conservative timeline for developing a conventional hydroelectric project, noting that EAs and EISs occur in the "License Application" stage. FERC guidelines for preparing EAs and EISs promote discussions between the licensee and various non-governmental organizations (NGO), individual citizens, and local, state, and federal agencies to ensure a comprehensive assessment is put forward. To this end, each entity can suggest protection, mitigation, and enhancement (PM\&E) measures to be included in the report, complete with FERC categorization of measure-type and estimates for initial capital expenditures and annual operations and maintenance $(\mathrm{O} \& \mathrm{M})$ costs. However, in the final EA or EIS, FERC will indicate which of these measures are required in the license.

A common outcome of the licensing process for most hydropower projects is that developers are required to implement multiple environmental mitigation measures. The costs of these mitigation measures can be significant, but due to the large size of most existing hydropower plants mitigations costs have historically constituted a smaller share of overall project costs. However, most of the remaining undeveloped hydropower resources in the U.S. are at sites with less than $500 \mathrm{MW}$ of potential capacity, with the top 100 sites exhibiting between 20 MW and 500 MW (Hadjerioua et al., 2012; Kao et al., 2014). For such smaller plants, the costs of environmental mitigation measures can become a binding constraint on the investment decision process. Thus, there is a crucial need to evaluate the pattern of environmental mitigation costs as a basis for understanding its implications for the future development of hydropower in the U.S. This report provides a review of the economics of environmental mitigation in the U.S. using data collected from 184 unique EAs and EISs reviewed by FERC for a variety of hydropower project types between 1996 and 2018.

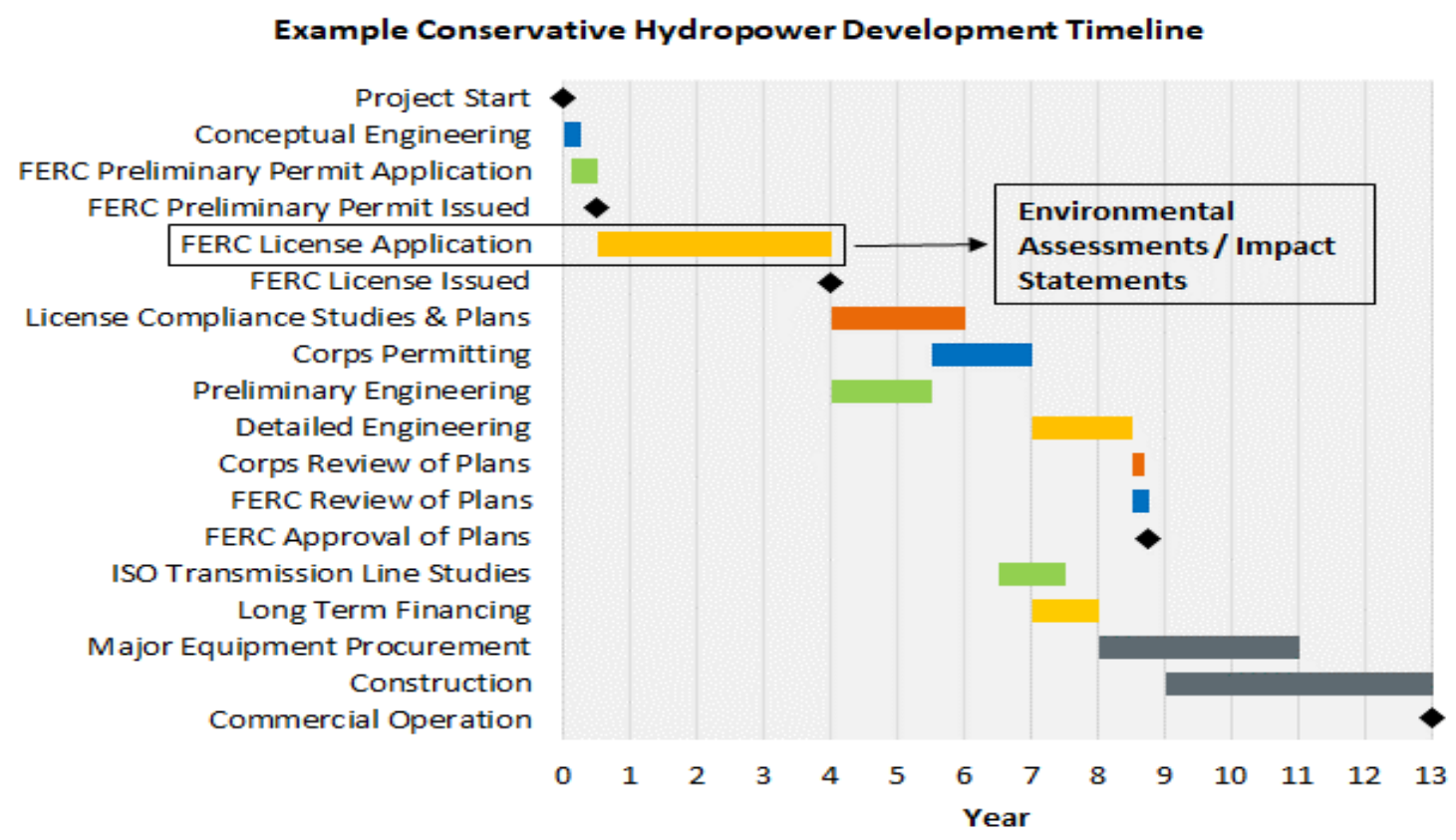

Figure 1: Example of a conservative hydropower development timeline for a project licensed by FERC. Source: Adapted from Meier et al. (2010). 


\section{METHODS}

\subsection{Existing Studies of Hydropower Environmental Mitigation Measures}

There is an extensive literature on the potential environmental impacts of hydropower and the associated mitigation measures required by the U.S. FERC licensing process; however, their discussion of the economics of environmental mitigation is limited. Paris et al. (2019) and Gracey and Verones (2016) are recent literature review studies that provide a comprehensive overview of metrics used for assessing the environmental impacts of hydropower and helped frame our approach. The few studies directly related to environmental mitigation requirements for hydropower licensing in the U.S. are briefly summarized below.

Schramm et al. (2016) collected and summarized environmental mitigation data for over 300 hydropower plants licensed or relicensed from 1998 to 2013. Their findings suggest that the majority of FERC mitigation requirements are related to either hydrologic flows or recreation, and that hydropower plants with the highest number of mitigation measures are found in the Pacific Northwest. These authors then conducted a complementary study (Derolph et al., 2016) and developed predictive models for identifying potential environmental mitigation requirements at proposed hydropower sites using this previously collected data. The models utilize a wide variety of site-specific input variables, from biological and hydrologic conditions to recreational uses, to predict potential mitigation requirements for a potential hydropower site. The studies by Schramm et al. (2016) and Derolph et al. (2016) did not collect or discuss the economics of environmental mitigation measures for the licensed or relicensed projects.

The Wisconsin Department of Natural Resources (WDNR, 2017) studied the environmental impacts, economic costs and benefits, applicable regulations, and potential policy alternatives of providing fish passage at dams in Wisconsin and other parts of the U.S. WDNR (2017) focused on the costs of fish passage (similar to some measures covered in this analysis) to determine if fish passage is economically beneficial. They found that costs are highly dependent on site-specific characteristics (dam size, fish species present, hydrology, etc.) and benefits are often difficult to quantify. The current study focuses solely on costs but covers many different types of environmental mitigation measures in addition to fish passage.

The closest effort to our study was by Hall et al. (2003), who evaluated the environmental mitigation costs of hydropower within a larger hydropower economic parameters study. They developed a series of regression curves for the various cost components of hydropower installation and operation, including five mitigation categories - fish and wildlife mitigation, recreation mitigation, water quality monitoring, fish passage, and historical and archeological mitigation. Overall, Hall et al. (2003) found a strong correlation between costs and installed capacity; however, water quality mitigation was switched to water quality monitoring because the former did not show a functional relationship with installed capacity. Additionally, fish passage was only considered if the project installed both upstream and downstream passageways. Although their analysis covered a large variety of project types-including NPD, New Stream-Reach Development (NSD), and capacity expansions - plants with <1 MW and $>1300 \mathrm{MW}$ installed capacity, Pumped Storage Hydropower (PSH), and relicensed hydropower were excluded.

The study described in this report builds on the Schramm et al. (2016), Derolph et al. (2016) and Hall et al. (2003) by extending the licensing years to 2018 (the former two used data prior to 2015; the latter used data prior to 2000), covering more project types (i.e. <1 MW and >1300 MW, relicenses, and PSH), and utilizing more extensive environmental mitigation categories. Additionally, our study complements the Schramm et al. (2016) and Derolph et al. (2016) studies by evaluating the economics of environmental mitigation. 


\subsection{Environmental Mitigation Cost Database Development}

For our study, we collected environmental mitigation data for all PM\&E measures included in the EA and EIS documents of the hydropower project sites, as well as their associated economic information, FERC categorization, and final FERC decision. This information was commonly found in the "Developmental Analysis" section of these reports. FERC compiles all documents relevant to hydropower licensing in their online eLibrary website, ${ }^{2}$ which we used to access the EA and EIS documents for the 184 projects included in our analysis. For the rest of this report, we refer to EA and EIS documents collectively as EA documents, or EAs, since our data were obtained from both sources, and differences between the two are not of high importance in our analysis. Due to the inherent variability in the file types (i.e. pdf, Microsoft Word document, or image) and structure of the EA documents (i.e. different table formats, page and section numbering styles, and section titles), we manually investigated each EA and consolidated all relevant PM\&E data in a Microsoft Excel spreadsheet, referred to below as the EA Cost Database.

Each data point in the EA Cost Database is a single PM\&E measure intended to alleviate a potential environmental impact associated with the construction and operation, or continued operation, of a hydroelectric facility. However, FERC extends the term "environment" to include both the human and ecological impacts of the facility. Measures related to both aquatic habitat and recreational facilities, for instance, are included in the EA documents. Each data point has an initial capital cost, annual O\&M cost, annualized cost, recommending entity, and FERC conclusion on whether it will be required in the license. The initial capital cost refers to the upfront cost of implementing the PM\&E measure, which typically has an associated annual O\&M cost that will be incurred throughout the plant's lifetime, but not all measures have both types of costs. For instance, measures that are related to maintaining a minimum or aesthetic spill flow typically only have an annual O\&M cost. On the other hand, some measures such as those related to implementing a specific type of management plan (i.e. wildlife or sediment, among many others) generally only have an initial capital cost as they only need to be conducted once, unless stated otherwise.

In addition to the PM\&E measures, we also collected facility-level data from the "Introduction" and "Developmental Analysis" sections of the EA documents. This data includes the installed capacity, FERC docket number, name, state, project type, economic data publishing year, period of economic analysis, term of financing, capacity factor, and annual generation. Since our data spans the period from 1996 to 2018, we used the economic data publishing year and the RSMeans cost index to escalate all the cost data to common 2018 values for level comparability across projects and years. Although the PM\&E measures are grouped into categories by FERC, these classifications are often inconsistently used by project applicants. Therefore, we developed a tiered classification scheme to group similar measures and better facilitate analysis, which is discussed in Section 2.4.

In total, we collected over 5,400 PM\&E measures for the 184 projects, nearly 4,400 of which were required by FERC in the project license. Inherent in any data analysis is the identification and handling of erroneous data points, in which we found three entire projects and 18 measures with questionable economic information. Thus, we excluded these from our analysis. In Appendix A, we address the reasons for removing individual measures from our remaining project list. Most exclusions pertain to the PM\&E measure having extremely high initial capital and/or O\&M costs. We collected annualized costs from the EA documents, but found that the process for determining these values varied across projects. Some licensees used extensive economic equations to estimate the annualized values, while others simply divided their initial capital and annual O\&M costs by their entire operating period. Accordingly, we excluded these inconsistent data values from our analysis.

\footnotetext{
${ }^{2}$ FERC eLibrary website: https://elibrary.ferc.gov/IDMWS/search/fercgensearch.asp
} 


\subsection{Hydropower Project Types}

For the purposes of this study, projects in the dataset are grouped into four major categories: 1) NPD; 2) NSD; 3) Relicensed Conventional Hydropower Dams (RCHD); and 4) PSH, which is subdivided into Relicensed (RPSH) and New (NPSH). Figure 2 shows the location of the projects by facility type. There is a preponderance of NPD and RCHD projects in the dataset, totaling 57 and 103 projects, respectively. Additionally, there are more projects in the eastern portion of the U.S. than in the West, with few projects in the central part of the country. Nearly all the NSD and NPSH projects are in the West, whereas the RPSH projects are in the East and Midwest. A brief description of each facility type is included below.

\section{Hydropower Facilities Used in the Environmental Mitigation Cost Model}

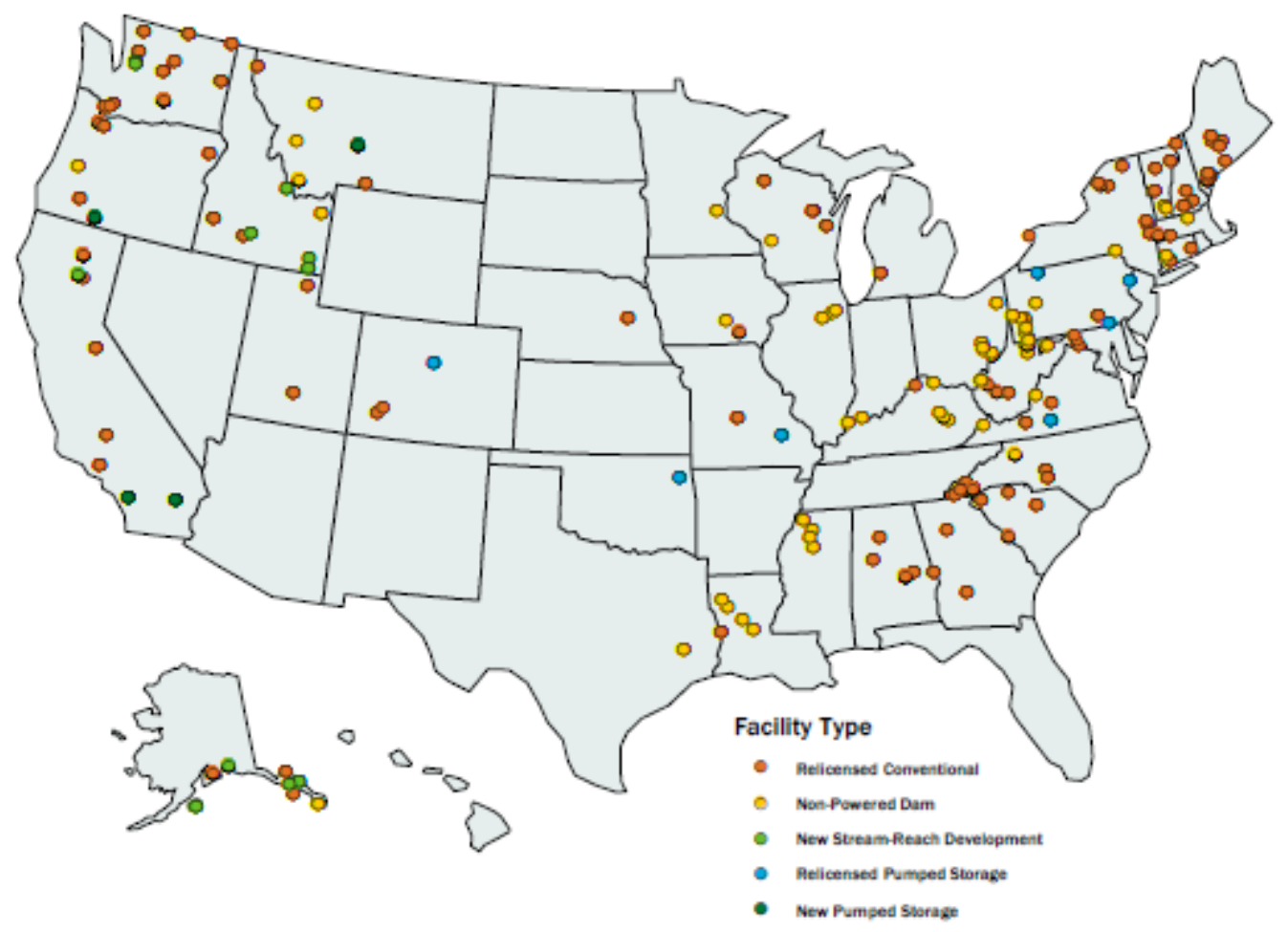

Figure 2: Map of facilities used in our analysis.

\subsubsection{Relicensed Conventional Hydropower Dams}

For the past century, RCHD projects have provided the U.S. with clean, affordable electricity by using dams to impound a water body and create a reservoir, which allows for regulated power generation. Because most of these were developed in the mid-twentieth century, they are either nearing or have already reached the end of their original 30- to 50-year licensing period (DOE, 2016). According to FERC, licensees must declare their intent to apply for a new license at least five years prior to original license expiration and submit their relicense application at least two years prior to expiration. Regardless of the EA requirement in the original license application, licensees must prepare a new EA for the relicense application to address any current or future environmental issues associated with the site. 


\subsubsection{Non-Powered Dams}

An NPD is any previously existing dam that does not have any hydroelectric generating capability and was instead originally built for purposes related to flood control, recreation, irrigation, water storage, or navigation. NPDs comprise a large portion of the U.S.'s hydropower potential and thus, of the 118 new developments since 2006, 40 of them have been NPDs (Uría-Martínez, 2018). The NPD data for this study were obtained from EA documents in the original license applications. Although FERC allows for an expedited licensing process for proposed NPD projects with installed capacities of $10 \mathrm{MW}$ or less, an EA is still required, similar to larger projects.

\subsubsection{New Stream-Reach Development}

NSD refers to any new hydroelectric development on previously un-dammed or undeveloped bodies of water. Similar to NPD projects, NSD projects also comprise a major portion of the U.S. hydropower potential. However, due to environmental concerns with developing relatively unaltered waterways, there are more significant costs and complications associated with this category of development. As such, only 5 of the 118 recent hydropower facilities commencing operation were NSDs (Uría-Martínez, 2018). The FERC licensing process resembles that of a conventional hydroelectric dam with lengthy license application timelines, including preparation of EA documents.

\subsubsection{Pumped Storage Hydropower}

Throughout the past century, PSH has proved to be an economically viable form of utility-scale energy storage across the world. Typical operation of a PSH facility involves using excess, or low-cost, electricity to pump water from a lower reservoir to an upper reservoir where it is stored. When more electricity is needed by the grid, the water is released back down to the lower reservoir through a powerhouse, generating electricity. Most existing PSH facilities in the U.S. were built in the midtwentieth century and as a result, are either nearing or have already reached the end of their original 30- to 50-year licensing periods (DOE, 2016). These facilities are typically large (>100 MW) and use an openloop configuration, which is defined by FERC as a continuous connection to a naturally flowing water feature. Accordingly, open-loop projects often have extensive EA requirements, much like conventional hydroelectric dams, due to the rapid nature of water transfer between the upper and lower reservoirs, one or both of which is located on a natural body of water. Similar to RCHD projects, RPSH have five years to declare intent for re-licensure prior to original license expiration and then, must submit their relicense application at least two years before that expiration. Although only one new PSH facility has commenced operation in the past 20 years (Uría-Martínez et al., 2014), there are many proposed PSH projects in the

pipeline. Most of these are closed-loop configurations, where the facility is not continuously connected to a naturally flowing water feature, as defined by FERC. Accordingly, lengthy license application timelines have the potential to be significantly reduced, as evident in the recent FERC Order under America's Water Infrastructure Act of 2018, which limits the license approval timeline to two years after submission (FERC, 2019). 


\subsection{Environmental Mitigation Data Classification Scheme}

FERC groups PM\&E measures based on common themes, such as their relation to aquatic, terrestrial, or geologic resources. However, this classification scheme is not always used consistently across projects, and for many, classifications are not even included. Given this, we developed a tiered classification scheme that is based on FERC's categories to ensure consistency and facilitate analysis of trends across all projects. We used 11 Tier 1 categories based primarily on the most widespread and descriptive FERC categories - aquatic species, cultural resources, geological resources, hydrology, land use and aesthetic resources, project operations, recreation resources, terrestrial resources, threatened and endangered species, water quality, and other. These categories are described in Table 1, along with example measures, and are visually represented in Figure 3. In addition to the FERC categories, the classification scheme in Table 1 reflects those used in existing environmental mitigation studies (Paris et al., 2019; Gracey and Verones, 2016; Schramm et al., 2016; Derolph et al., 2016), as well as the need to group related cost items. As a result, the Tier 1 PM\&E categories in Table 1 are more detailed than in most of the existing studies.

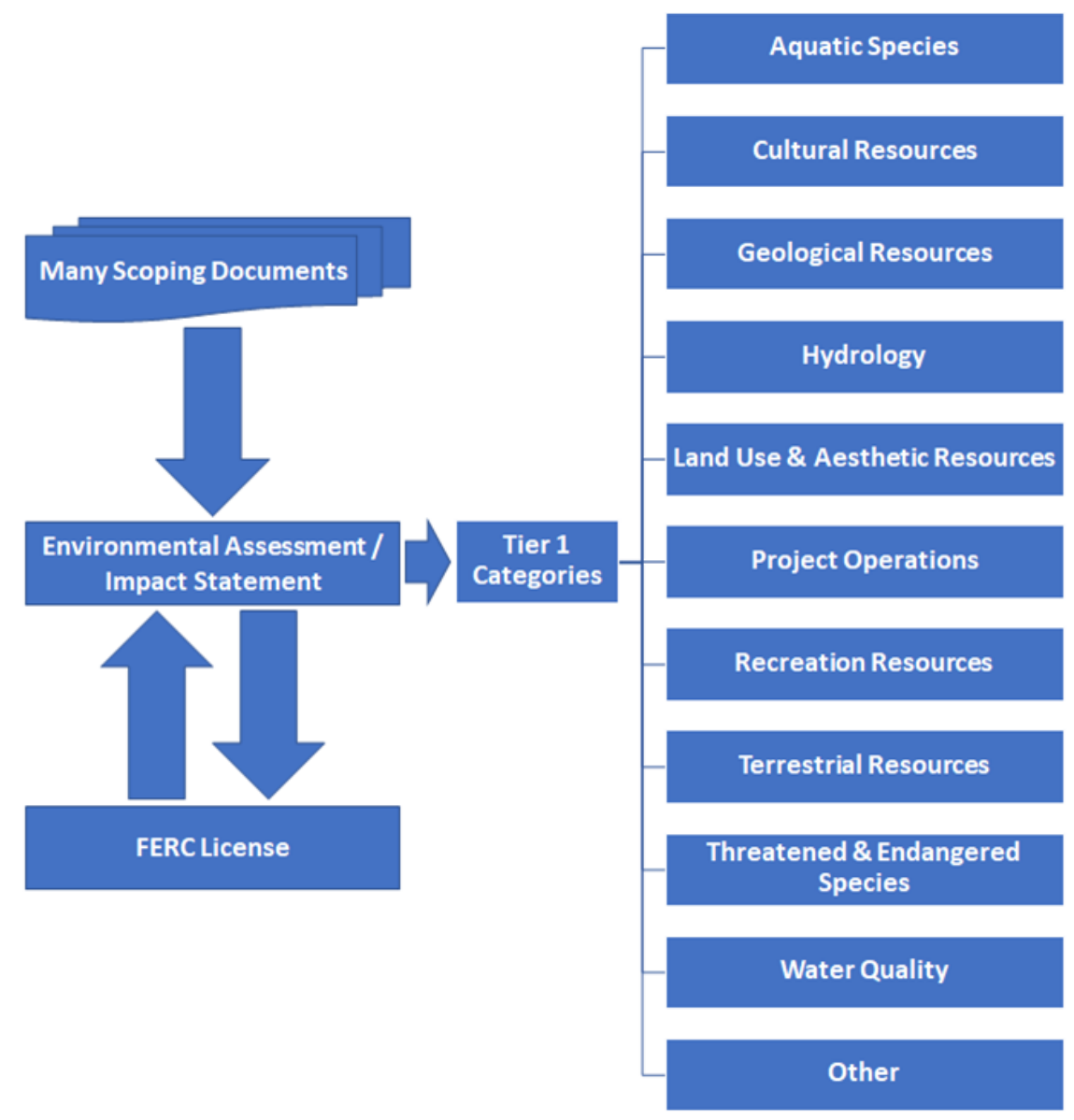

Figure 3: Tiered classification scheme for PM\&E measures. 
Table 1: Description of Tier 1 PM\&E Categories

\begin{tabular}{|c|c|c|}
\hline Category & Description & Example Measures \\
\hline Aquatic Species & $\begin{array}{l}\text { Measures to protect aquatic wildlife } \\
\text { and habitat, including facilitating } \\
\text { fish passage. }\end{array}$ & $\begin{array}{l}\text { Fish passage, biotic monitoring, } \\
\text { habitat management plans, invasive } \\
\text { species control plans. }\end{array}$ \\
\hline Cultural Resources & $\begin{array}{l}\text { Measures to protect historic } \\
\text { structures, areas, or artifacts. }\end{array}$ & $\begin{array}{l}\text { Avoidance of burial grounds, } \\
\text { notification of native peoples upon } \\
\text { artifact discovery. }\end{array}$ \\
\hline Geological Resources & $\begin{array}{l}\text { Measures to protect against soil } \\
\text { erosion, sediment accumulation, } \\
\text { and hazardous waste. }\end{array}$ & $\begin{array}{l}\text { Sediment control plans, erosion } \\
\text { control plans, contaminated soils } \\
\text { removal. }\end{array}$ \\
\hline Hydrology & $\begin{array}{l}\text { Measures that relate to maintaining } \\
\text { certain hydrologic conditions } \\
\text { through the facility. }\end{array}$ & $\begin{array}{l}\text { Flow requirements, hydraulic } \\
\text { studies. }\end{array}$ \\
\hline Land Use and Aesthetic Resources & $\begin{array}{l}\text { Measures that call for land } \\
\text { acquisition, promote compliance } \\
\text { with existing land use patterns, } \\
\text { and/or minimize visual } \\
\text { disturbances. }\end{array}$ & $\begin{array}{l}\text { Acquiring land rights, matching } \\
\text { project aesthetics to style of } \\
\text { surrounding areas, reducing } \\
\text { project-related noise pollution. }\end{array}$ \\
\hline Project Operations & $\begin{array}{l}\text { Measures to improve facility } \\
\text { operation. }\end{array}$ & $\begin{array}{l}\text { Turbine-generator unit installation, } \\
\text { access, signage, management plans. }\end{array}$ \\
\hline Recreation Resources & $\begin{array}{l}\text { Measures to implement new } \\
\text { recreation opportunities or } \\
\text { accommodate those affected by } \\
\text { construction and operation. }\end{array}$ & $\begin{array}{l}\text { Provision of boat ramps, } \\
\text { campgrounds, fishing platforms, } \\
\text { parking lots, restrooms, prescribed } \\
\text { flow or water levels for boating. }\end{array}$ \\
\hline Terrestrial Resources & $\begin{array}{l}\text { Measures that protect land animals, } \\
\text { avian populations, and vegetation. }\end{array}$ & $\begin{array}{l}\text { Replanting of vegetation on } \\
\text { disturbed areas, establish } \\
\text { transmission corridors, protection } \\
\text { plans for birds and animals. }\end{array}$ \\
\hline $\begin{array}{l}\text { Threatened and Endangered } \\
\text { Species }\end{array}$ & $\begin{array}{l}\text { Measures designed for protection } \\
\text { of specific threatened and } \\
\text { endangered species. }\end{array}$ & $\begin{array}{l}\text { Relocating wildlife, conducting } \\
\text { studies on population dynamics, } \\
\text { ongoing protection plans. }\end{array}$ \\
\hline Water Quality & $\begin{array}{l}\text { Measures that specify conditions } \\
\text { for safeguarding water quality. }\end{array}$ & $\begin{array}{l}\text { Dissolved oxygen monitoring, spill } \\
\text { prevention and disposal plans, } \\
\text { aeration. }\end{array}$ \\
\hline Other & $\begin{array}{l}\text { Measures that do not qualify for } \\
\text { other categories and have low } \\
\text { sample sizes. }\end{array}$ & $\begin{array}{l}\text { Reporting, annual payment plans, } \\
\text { environmental compliance plans. }\end{array}$ \\
\hline
\end{tabular}




\section{ENVIRONMENTAL MITIGATION COST DATA ANALYSIS}

\subsection{Overview of PM\&E Capital and O\&M Costs}

Figure 4 provides a broad view of capital costs per project for all PM\&E measures in our dataset on a $\$ / \mathrm{kW}$ basis in $2018 \$$. Facility type, number of measures, and installed capacity are indicated by the shape, color, and size of the points, respectively. The y-axis is plotted logarithmically to better display the data. The capital PM\&E costs per project cover a wide range, from below $\$ 1 / \mathrm{kW}$ to nearly $\$ 6000 / \mathrm{kW}$, with most projects falling below $\$ 250 / \mathrm{kW}$. RCHD, NSD, and NPD projects have the highest capital costs per $\mathrm{kW}$, unlike PSH where most projects fall below $\$ 100 / \mathrm{kW}$. Notably, RPSH projects have the lowest capital costs of all project types, excluding RCHD projects with no capital costs. The large capital costs for RCHD projects partly reflects the imposition of environmental mitigation requirements that were not required in the original license, and new environmental concerns arising from the operation of the facility. At the same time, there are many RCHD projects with low capital costs on a per $\mathrm{kW}$ basis, reflecting economies of scale (i.e. large capacities reduce per $\mathrm{kW}$ capital costs). Likewise, the low per $\mathrm{kW}$ capital costs for PSH also are partly due to economies of scale, in addition to several facilities being closed-loop (i.e. NPSH) and thereby, having fewer impacts on natural ecosystems. Regarding the number of all PM\&E measures required by FERC in the license, most projects have roughly 20-30 measures with few having more than 100 measures listed. Although there is no general relationship between the number of measures and capital costs per $\mathrm{kW}$, projects with the highest number of measures (yellow and green colors in Figure 4) are almost all above $\$ 100 / \mathrm{kW}$.

Figure 5 shows that per project O\&M costs for PM\&E measures range from a few cents $/ \mathrm{kW}$ to about $\$ 200 / \mathrm{kW}$, with most projects falling below $\$ 40 / \mathrm{kW}$. Although the different project types are wellrepresented across the range of O\&M costs on a per $\mathrm{kW}$ basis, PSH projects generally have much lower O\&M costs, excluding the few projects with no O\&M costs. RCHD projects follow a similar pattern for O\&M, as with capital costs, having both high and low values that can be attributed to economies of scale and new environmental mitigation measures that were not required in their original licenses. 


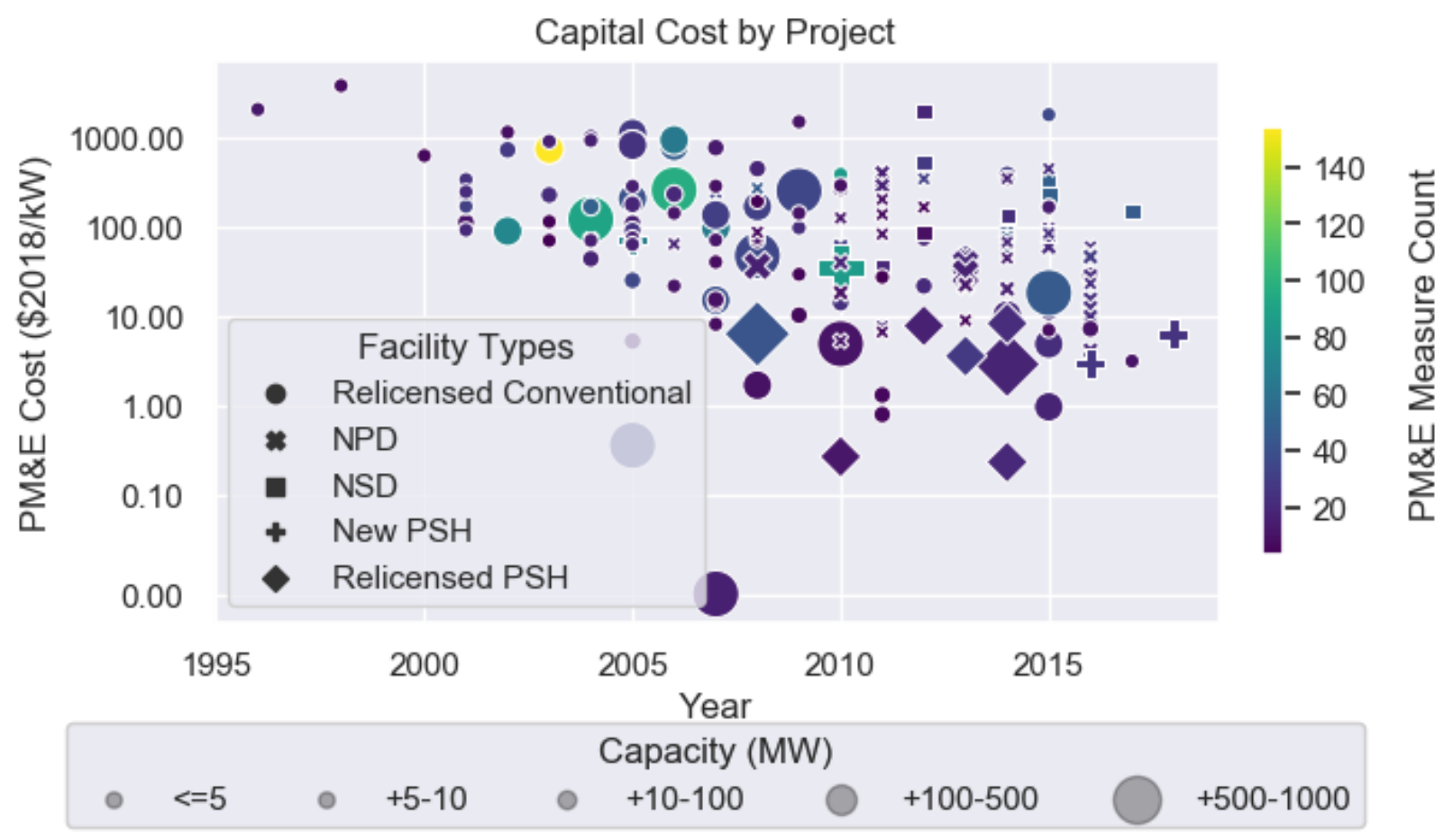

Figure 4: Capital PM\&E Costs by Year, Installed Capacity, and PM\&E Measure Count for all 181 projects in our dataset.

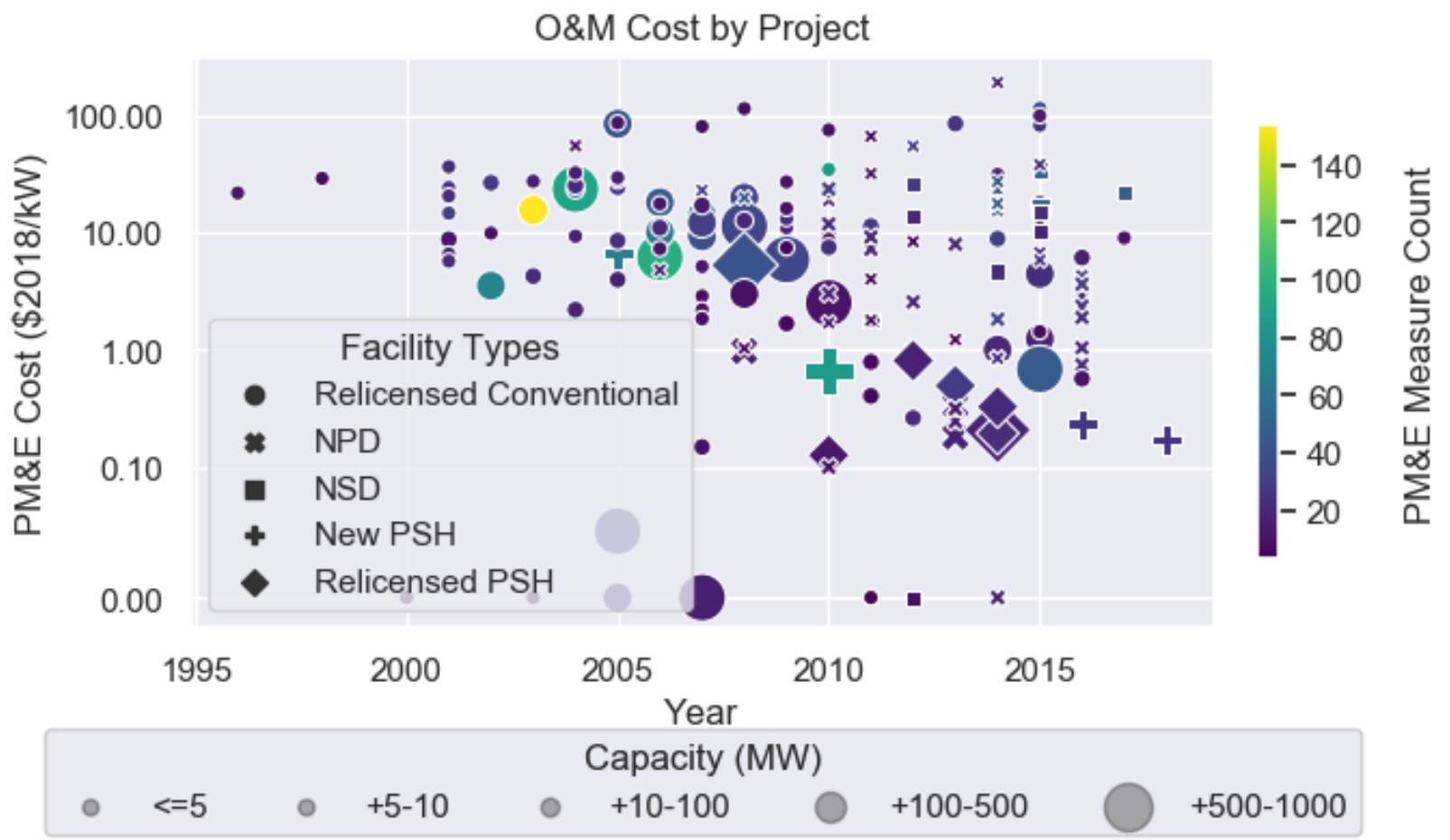

Figure 5: O\&M PM\&E Costs by Year, Installed Capacity, and PM\&E Measure Count for all 181 projects in our dataset. 


\subsection{PM\&E Costs for Relicensed Conventional Hydropower Dams}

RCHD projects account for 103 of the 181 projects in our dataset with licensure occurring from 1996 to 2017. The average installed capacity is $141 \mathrm{MW}$ over a range of 0.060 to $2,755 \mathrm{MW}$. The total PM\&E measure count is 3,161 , or an average of 31 per project, but these are reduced to 2,451 and 24 with the exclusion of non-mandatory measures. Figure 6 provides statistics on the distribution of PM\&E costs for RCHD projects by our Tier 1 categories, with each category as a subplot on different scales for better visualization. The boxes represent the interquartile range (IQR), which is the distance between the 75th and 25th percentile values, while the whiskers bound the upper and lower limits of the data. Outliers were determined as those outside of $1.5^{*} \mathrm{IQR}$ and subsequently, were excluded from graphing. Because all values are bounded below by zero, the bottom edge of the box and lower whisker are the same in many cases. Additionally, not all projects have capital and/or O\&M costs for particular mitigation categories, which leads to zero median values for a number of the capital and O\&M costs.

Of all the mitigation categories, Aquatic Species has the highest median values for both capital costs (about $\$ 50 / \mathrm{kW}$ ) and annual O\&M costs (about $\$ 4 / \mathrm{kW}$ ). Median capital costs for Project Operations, Geological Resources, Recreation Resources, Terrestrial Resources, and Water Quality are between $\$ 2 / \mathrm{kW}$ and $\$ 20 / \mathrm{kW}$, but median capital and O\&M costs for most of the other categories are generally below $\$ 1 / \mathrm{kW}$. Aquatic Species and Project Operations have the largest range of capital costs with the upper IQR at nearly $\$ 200 / \mathrm{kW}$, followed by Recreation Resources at $\$ 40 / \mathrm{kW}$, and the other categories at less than $\$ 20 / \mathrm{kW}$. The IQR of O\&M costs for all categories are much narrower and more evenly spread across categories than capital costs, with most falling under $\$ 10 / \mathrm{kW}$. These results show that RCHD projects are required to meet potentially costly mitigation measures, particularly related to Aquatic Species, Project Operations and Recreation Resources. Furthermore, there are three erroneous PM\&E measures that severely inflate the economics of several projects and hence, were preemptively excluded from the calculations resulting in Figure 6. Two of these were capital cost for Water Quality and Other that are over $\$ 500 / \mathrm{kW}$ and, by themselves, extend far beyond the IQR of the projects contained in the RCHD dataset (i.e. an individual measure costs more than all other measures within those categories for each of the 103 RCHD projects). Another outlier measure was in Aquatic Species, which had an extremely high O\&M cost of $\$ 18$ million with no initial capital cost and was listed as a temporary value. This was the largest O\&M value across all RCHD projects. There were five other measure outliers that were removed by filtering out non-mandatory measures. 


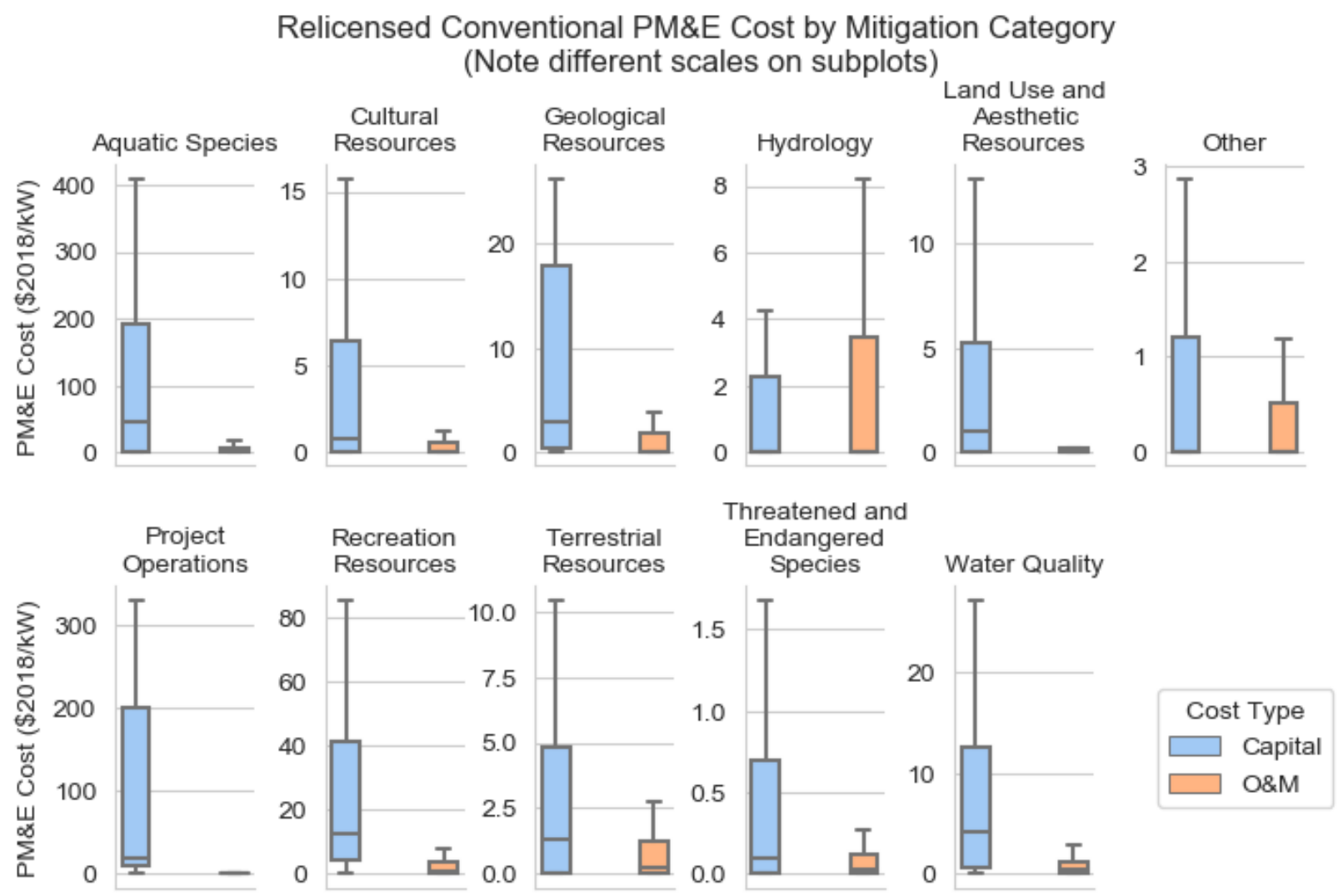

Figure 6: Capital and O\&M PM\&E Costs for the 103 Relicensed Conventional projects across the 11 Mitigation Categories.

\subsection{PM\&E Costs for Non-Powered Dams}

NPD projects are the second largest in the dataset, containing 57 licensed projects within the past 2 decades. The installed capacities of these projects ranged from 0.076 to $190 \mathrm{MW}$, with an average project capacity of $19 \mathrm{MW}$. Compared to the RCHD average of $174 \mathrm{MW}$, NPD projects are remarkably smaller in capacity. In total, the NPD projects had 1,455 PM\&E measures with an average of 26 per project; however, after controlling for those not required in the license by FERC, these values drop to 1,235 and 22, respectively. Each of these averages are lower than that of RCHD projects, which are 31 and 24, respectively. Figure 7 illustrates the distribution of capital and O\&M PM\&E costs across our Tier 1 categories for NPD projects. Similar to RCHD projects, all values are bounded below by zero, so the lower whisker and bottom edge of the box are the same in some cases. Furthermore, not all projects have capital and O\&M costs for a given mitigation category, lowering the median to near zero in several instances. Particularly, Project Operations has only one measure across all 57 NPD projects, which has zero values for both capital and O\&M.

For mitigation category trends, we see that Recreation Resources and Water Quality exhibited the highest medians for initial capital (about $\$ 16 / \mathrm{kW}$ ) and annual O\&M expenditures (about $\$ 4 / \mathrm{kW}$ ), respectively. This contrasts with RCHD projects where Aquatic Species have the highest per kW costs. We imagine these two categories being of higher importance for NPD projects out of the need to prevent hydroelectric operation from interfering with the existing purposes of the impoundment (i.e. recreation and/or water supply). For median capital costs, most of the other mitigation measures are between $\$ 1 / \mathrm{kW}$ and $\$ 5 / \mathrm{kW}$ with Hydrology, Land Use and Aesthetic Resources, and Threatened and Endangered Species falling 
below $\$ 1 / \mathrm{kW}$. Much like RCHD, median O\&M costs are less than $\$ 1 / \mathrm{kW}$ for the majority of mitigation measures. The IQR of capital costs for most NPD projects is quite narrow, falling well within $\$ 10 / \mathrm{kW}$, except for Aquatic Species with an upper IQR of nearly $\$ 41 / \mathrm{kW}$, Recreation Resources at $\$ 28 / \mathrm{kW}$, and Water Quality at $\$ 16 / \mathrm{kW}$. This pattern mimics RCHD very closely, albeit the upper quartile of Aquatic Species is much higher for RCHD at roughly $\$ 200 / \mathrm{kW}$. For O\&M, the IQR is even narrower with an upper quartile of under $\$ 2 / \mathrm{kW}$ for nearly all projects, much like RCHD. Similar to RCHD, there are no measure outliers presented in Figure 7.

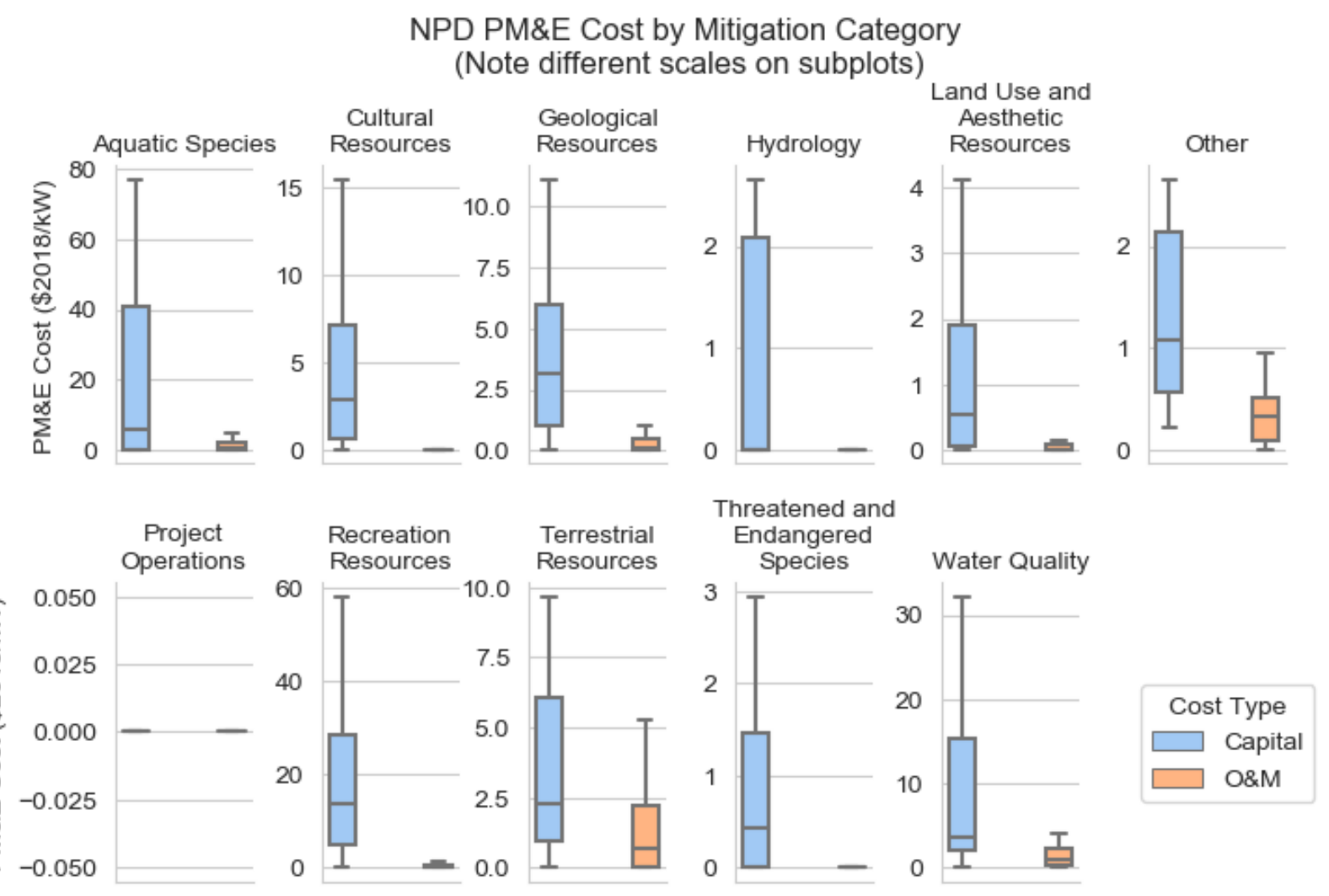

Figure 7: Capital and PM\&E Costs for the 57 NPD projects across the 11 Mitigation Categories.

\subsection{PM\&E Costs for New Stream-Reach Developments}

Our NSD dataset contains 11 projects, all licensed within the past decade. Compared to RCHD and NPD, most of these projects are smaller with an average installed capacity of $7 \mathrm{MW}$ over a range of 0.090 to 20 MW versus $141 \mathrm{MW}$ and $19 \mathrm{MW}$, respectively. Similarly, NSD had a much smaller number of PM\&E measures, totaling 379 prior filtering out non-mandatory measures and 303 upon filtering. However, NSD has a higher average number of measures per project at 35 and 28 for non-filtered and filtered measures, compared to NPD's 26 and 22, and RCHD's 31 and 24, respectively. This mostly likely stems from RCHD involving relicensing existing facilities and NPD development occurring at previously dammed, and hence are already environmentally altered, sites contrary to NSD, which involves undeveloped bodies of water. Thus, the latter inherently has more stringent and numerous mitigation requirements. Figure 8 shows how capital and O\&M PM\&E costs are distributed among our Tier 1 categories for the NSD projects. As shown previously, the lower whisker and bottom edge of the box are the same in some cases due to all values being bounded by zero. Additionally, several mitigation categories have only a few measures with nonzero values, lowering the median to near zero. 
Across all 11 NSD projects, no Project Operations measures were reported so this category is excluded from Figure 8. Of the remaining categories, Geological Resources and Aquatic Species appear to have the highest medians for initial capital (about $\$ 50 / \mathrm{kW}$ ) and annual O\&M costs (about $\$ 4 / \mathrm{kW}$ ), respectively, in contrast with Recreation Resources and Water Quality for NPDs. This can potentially result from NPDs involving previously existing impoundments, where aquatic species would have been displaced numerous years prior to retrofitting and the surrounding riverine system has acclimated to the presence of a dam and its previously existing spill flow regime. Additionally, more excavation and sediment control will be necessary for construction of a new dam and impoundment facility for NSD projects. Therefore, an NPD developer would be more focused on maintaining and/or improving existing recreation opportunities and water quality than aquatic species and geology. However, when compared to RCHD, both highest median values are the close even though the category with the highest median was Aquatic Species for RCHD (the category with the highest median O\&M cost is shared between NSD and RCHD). This is possibly due to RCHD projects needing to rectify previous harm and prevent future harm to aquatic species, while NSD typically involves smaller rivers and stream where less aquatic species would be present Additionally, NSD sites may have to devote more resources to mitigating any adverse geological effects from the construction and operation of a new facility. As for the remainder of the categories, most median capital costs are between $\$ 2 / \mathrm{kW}$ and $\$ 10 / \mathrm{kW}$, except for Terrestrial Resources at nearly $\$ 39 / \mathrm{kW}$. Similar to NPD projects, Land Use and Aesthetic Resources and Hydrology fall below $\$ 1 / \mathrm{kW}$. The per kW capital costs IQR are much less evenly spread across measures for NSD projects for than those of RCHD and NPD projects, with only about half falling within $\$ 10 / \mathrm{kW}$. Hydrology, Geological Resources, and Terrestrial Resources exhibit an IQR of nearly $\$ 50 / \mathrm{kW}$, followed closely by Recreation Resources at roughly $\$ 25 / \mathrm{kW}$. Similar to RCHD and NPD, the IQR for O\&M is quite narrow with an upper quartile of nearly $\$ 5 / \mathrm{kW}$ for most categories. As with the two previous sub-sections, no outliers are plotted in Figure 8. 


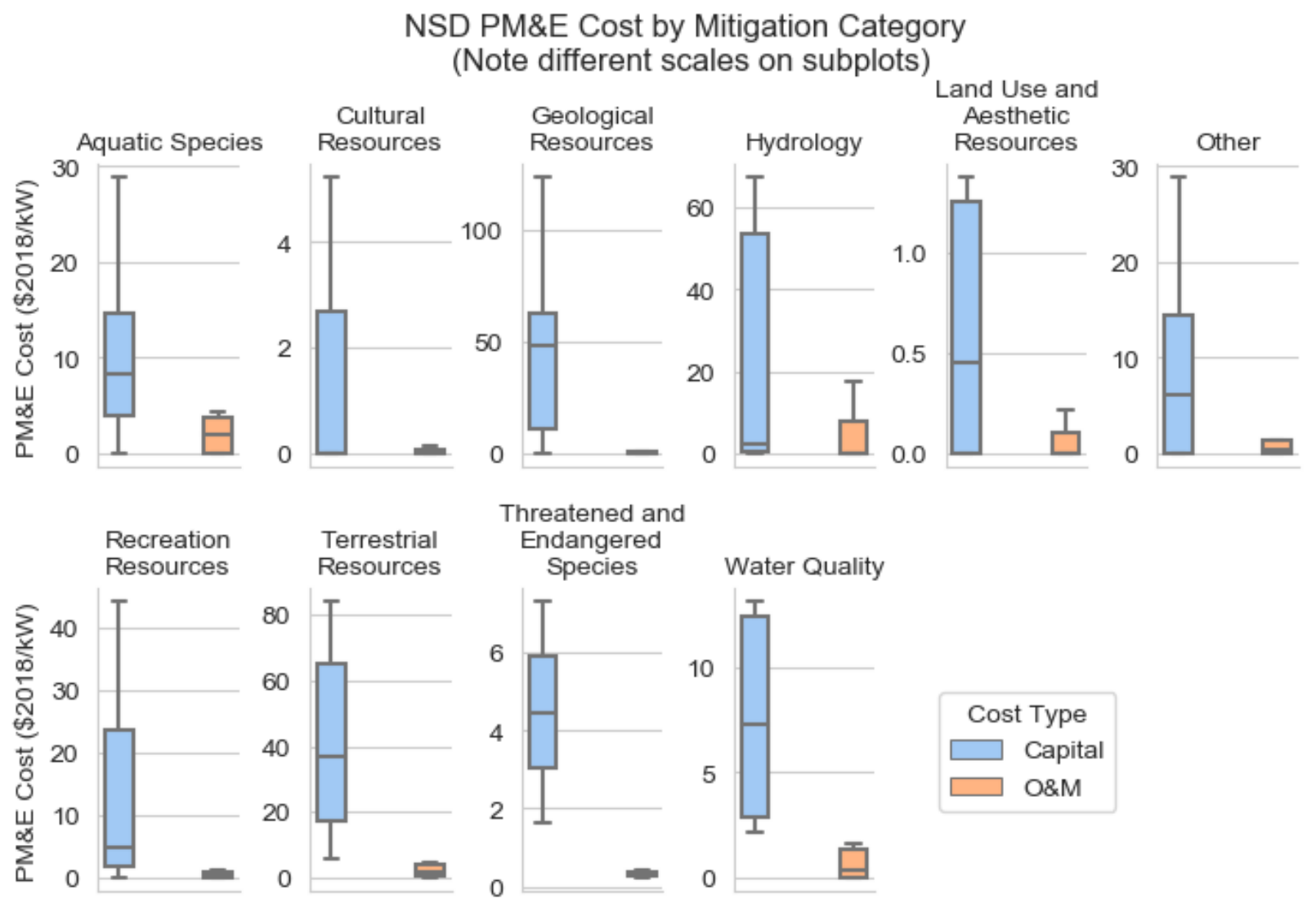

Figure 8: Capital and O\&M PM\&E Costs for the 11 NSD Projects across the 10 Mitigation Categories. Note that there were no Project Operations measures for any of the 11 projects.

\subsection{PM\&E Costs for Relicensed Pumped Storage Hydropower}

Our dataset includes six PSH projects relicensed between 2008 and 2014 with an average installed capacity of $489 \mathrm{MW}$ per project (range of 260 to $800 \mathrm{MW}$ ). Compared to other project types in our dataset, RPSH projects have much higher installed capacities; however, this is coupled with a significantly lower project sample size. The total number of PM\&E measures across all projects is 224 , which is much lower than those of RCHD, NPD, and NSD, and mainly correlated with the small sample size as the per project average is 32, closely resembling RCHD. After removing the non-mandatory measures, these values become 160 and 23, respectively, with the average falling in between RCHD and NPD. Figure 9 illustrates the distribution of initial capital and annual O\&M PM\&E costs for our Tier 1 categories across the RPSH projects. As previously discussed, some of the categories have boxes that override the lower whisker due to the lower bound of zero, and several categories have medians near zero due to a lack of many nonzero measures. Similar to NPD, Project Operations only has one measure across all six projects, which has zero values for capital and O\&M costs.

Nearly all the RPSH data are under $\$ 1 / \mathrm{kW}$ for capital and O\&M costs across the 11 mitigation categories, partly due to the large installed capacities of the facilities in our dataset. Like NPD projects, Recreation Resources have the highest median for capital and O\&M costs; however, it nearly ties with Water Quality for O\&M costs. This indicates that recreation is an important mitigation category for relicensing PSH facilities, which could potentially be due to larger facilities typically necessitating more recreational opportunities. The IQR of most of the mitigation measures is quite narrow, much more so than any of the 
previous project types, at under $\$ 1 / \mathrm{kW}$ for both capital and O\&M costs. However, Recreation Resources and Other have IQRs between $\$ 1 / \mathrm{kW}$ and $\$ 4 / \mathrm{kW}$, showcasing some variance in project costs.

Furthermore, several mitigation measures have O\&M IQRs that are much wider than their corresponding capital IQRs, which has only been previously seen in Hydrology for RCHD. These are Hydrology, Aquatic Species, Land Use and Aesthetic Resources, Water Quality, and Terrestrial Resources. There is one measure outlier excluded from the Project Operations category in Figure 9 (the other outlier was excluded by controlling for mandatory measures). The capital cost totaled $\$ 242 / \mathrm{kW}$, placing it far outside the existing cost range (IQR and whiskers) for Project Operations and the rest of the categories, which are below $\$ 10 / \mathrm{kW}$.

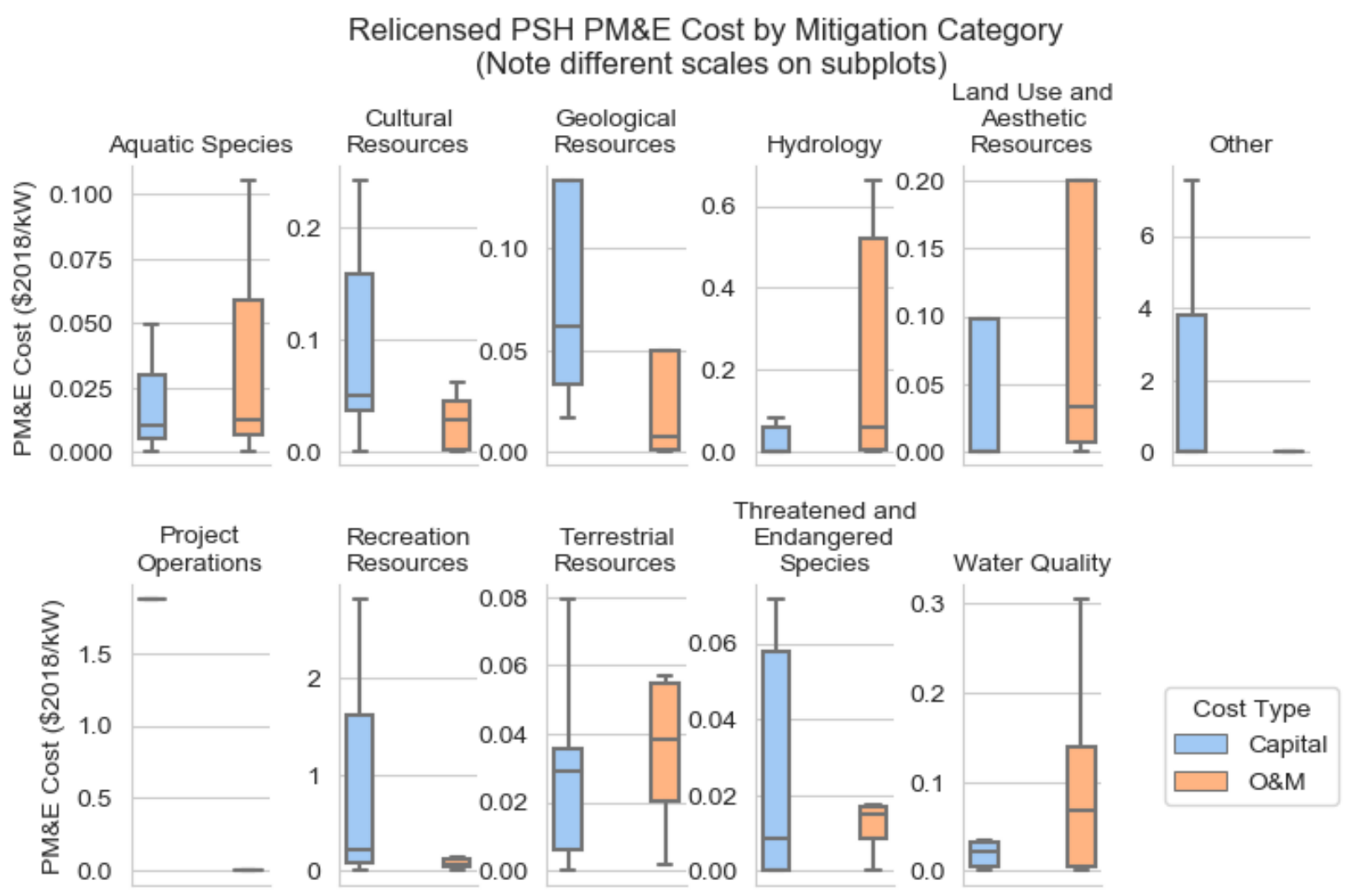

Figure 9: Capital and O\&M PM\&E Costs for the 6 Relicensed PSH projects across the 11 Mitigation Categories.

\subsection{PM\&E Costs for New Pumped Storage Hydropower}

NPSH was the smallest group in our dataset with only 4 out of 181 projects license application reviews between 2005 and 2018. The average installed capacity is $759 \mathrm{MW}$ over a range of 393 to 1,300 MW. As such, these are some of the largest projects in our dataset, which is characteristic of NPSH (and more broadly PSH) development across the US and world. The total PM\&E measure count is 244, or an average of 61 per project; however, these are reduced to 207 and 52, respectively, with the exclusion of non-mandatory measures. The large average number of measures is likely related to the installed capacity of NPSH. Figure 10 provides statistics on the distribution of PM\&E capital and O\&M costs for NPSH installations, divided into our 11 Tier 1 categories. As shown before, the lower whisker and bottom edge 
of the boxes are occasionally the same due to the lower bound of zero, and several categories have medians near zero due having only a few measures with nonzero costs.

Figure 10 shows that NPSH PM\&E costs are generally much lower than those of the other project types, except RPSH. Project Operations has the highest median capital cost at slightly under $\$ 5 / \mathrm{kW}$, followed by Terrestrial Resources at roughly $\$ 3 / \mathrm{kW}$, and the remainder of categories below $\$ 2 / \mathrm{kW}$. This is a more unique trend as the other project types never had Project Operations or Terrestrial Resources with the highest medians. This is likely due to the construction and excavation involved in creating and connecting the two reservoirs, as well as the costs of installing transmission systems. Additionally, the closed-loop nature of these projects explains why Aquatic Species and Water Quality make up a very small number of measures (4 and 7 respectively) across all four projects, since many aquatic species would likely not be native to these largely man-made bodies of water. As for O\&M, the median for each category is significantly below $\$ 1 / \mathrm{kW}$. The capital cost IQRs are largest for Project Operations and Recreation Resources, with the upper quartile approximately $\$ 10 / \mathrm{kW}$. Terrestrial Resources and Hydrology follow closely with upper quartiles near $\$ 7 / \mathrm{kW}$ and Geological Resources at $\$ 4 / \mathrm{kW}$. The remainder of the categories fall below $\$ 1 / \mathrm{kW}$ for capital costs. The O\&M cost IQRs is noticeably narrower with most categories falling significantly under $\$ 1 / \mathrm{kW}$, except for Other with an upper quartile of $\$ 3 / \mathrm{kW}$. These results largely show that economies of scale impact NPSH development favorably when compared to the other forms of hydropower development analyzed in our study. While individual measures may be costly, and may be rather numerous for each project, project sizes and energy contributions work to defray these costs. Following previous projects types, there are not many measure outliers requiring exclusion for NPSH. The Project Operations category had one with an initial capital cost of $\$ 144 / \mathrm{kW}$, which, as a singular measure, extends far beyond the upper whisker limit of approximately $\$ 20 / \mathrm{kW}$. Similarly, the other outlier measure was contained in Hydrology and exhibited a capital cost of $\$ 42 / \mathrm{kW}$, far above the nearly $\$ 7 / \mathrm{kW}$ upper limit for the Hydrology projects. 


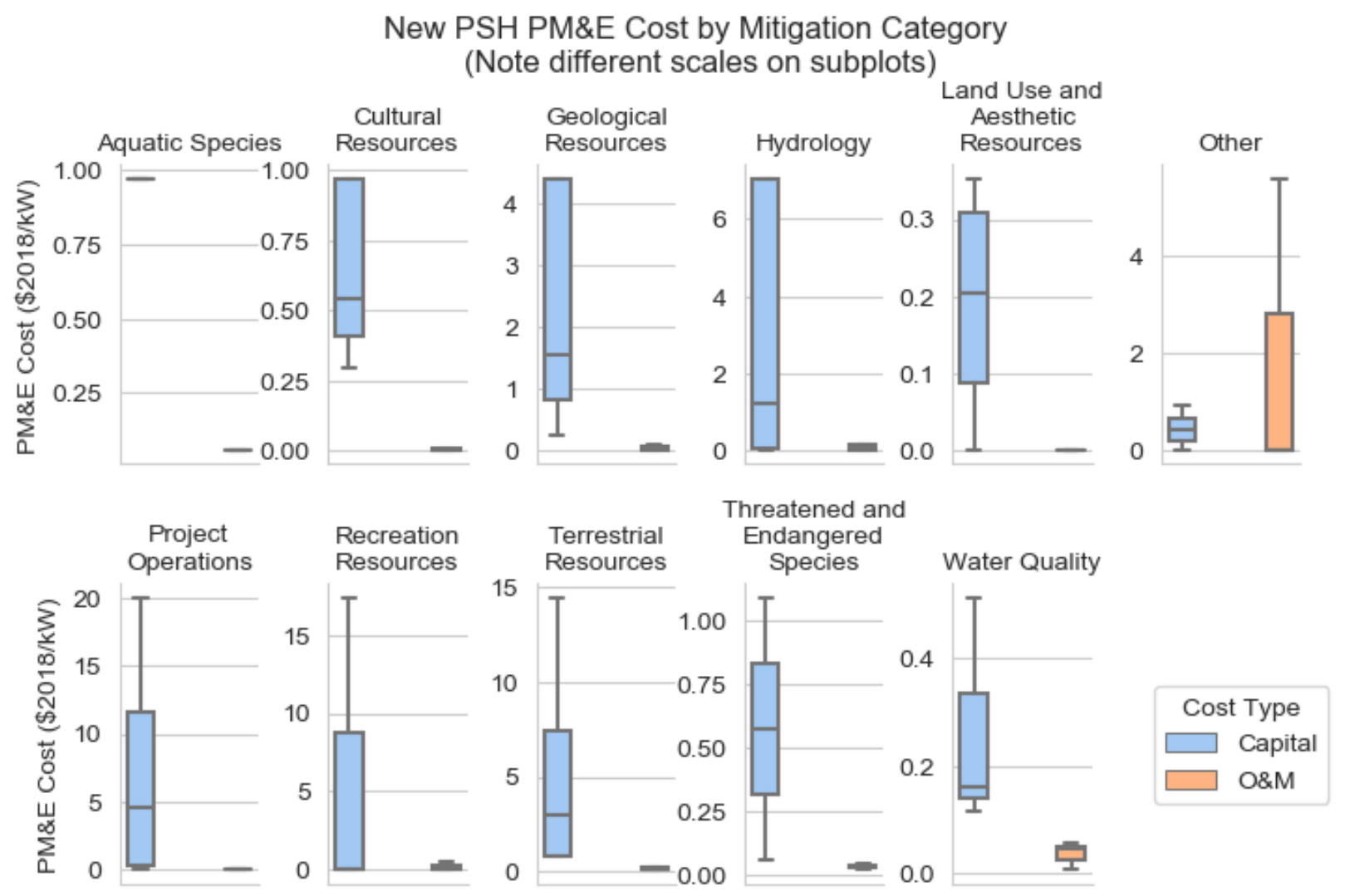

Figure 10: Capital and O\&M PM\&E Costs for the 4 New PSH projects across the 11 Mitigation Categories.

\subsection{Levelized Costs of PM\&E Across RCHD, NPD, and NSD Projects}

To compare costs across projects, the economic data from the EAs are used to estimate the levelized cost of energy (LCOE) specific to PM\&E. These were calculated ${ }^{3}$ for each project in $2018 \$$. The $10 \mathrm{PSH}$ projects are excluded from the LCOE calculation due to their operational nature complicating the LCOE calculation procedure (i.e. PSH projects both use and generate electricity, typically at a net energy consumption). Figure 11 shows project-level PM\&E LCOE (pLCOE) estimates for NPD projects in descending order, with two cost components illustrated: blue representing the portion due to capital costs, and orange representing the portion due to annual O\&M costs. NPD pLCOE estimates span a range of $\$ 0.10 / \mathrm{MWh}$ to roughly $\$ 60 / \mathrm{MWh}$, with the majority of pLCOE values falling below $\$ 15 / \mathrm{MWh}$. The share of pLCOE in total project LCOE has also been estimated and is displayed by yellow dots, tied to the right-hand vertical axis. These estimates result from total project LCOEs that are calculated using reported total project costs, both capital and O\&M, provided in the "Developmental Analysis" section of

${ }^{3}$ LCOE calculation relied on the following formula:

$L C O E=\frac{(C * C R F)+O M}{8760 * c f}$ Where: $\mathrm{C}=$ capital cost, $\mathrm{OM}=$ annual operations and maintenance cost, $\mathrm{cf}=$ capacity factor $=\frac{\text { Average annual generation }}{\text { (Installed capacity } * 8760)}$, and CRF $=$ capital recovery factor. CRF in this case is based on an interest rate of $6 \%$ for all projects, and a term of 30 years, leading to a constant value of 0.0725 . This is a simplification, since individual projects in this sample cover an interest rate range of 2-14\%; however, it better facilitates comparison across projects. (All projects reported a Period of Analysis of 30 years). For purposes of splitting LCOE: $L C O E O \& M=\frac{O M}{8760 * c f}$ and LCOE Capital $=\frac{(C * C R F)}{8760 * c f}$ 
each EA. The two categories of pLCOE are summed and a percentage is taken using this value and the overall project LCOE. These percentages range from 0 to $30 \%$ and are mostly concentrated just under $10 \%$. Figure 12 illustrates similar data for NSD projects with a narrower pLCOE span of \$1/MWh to nearly $\$ 40 / \mathrm{MWh}$. Similar to NPD projects, the share of pLCOE in total LCOE of NSD projects are generally between 10 and $25 \%$, with a small number of projects outside either end of that range. Due to the lack of facility-level economic data presented in EAs, Figure 13 shows pLCOE, for RCHD projects without the percentages that were included in previous plots. RCHD pLCOE spans \$0.08/MWh to nearly \$70/MWh, with most projects falling below \$30/MWh, which is consistent with NPD and NSD projects.

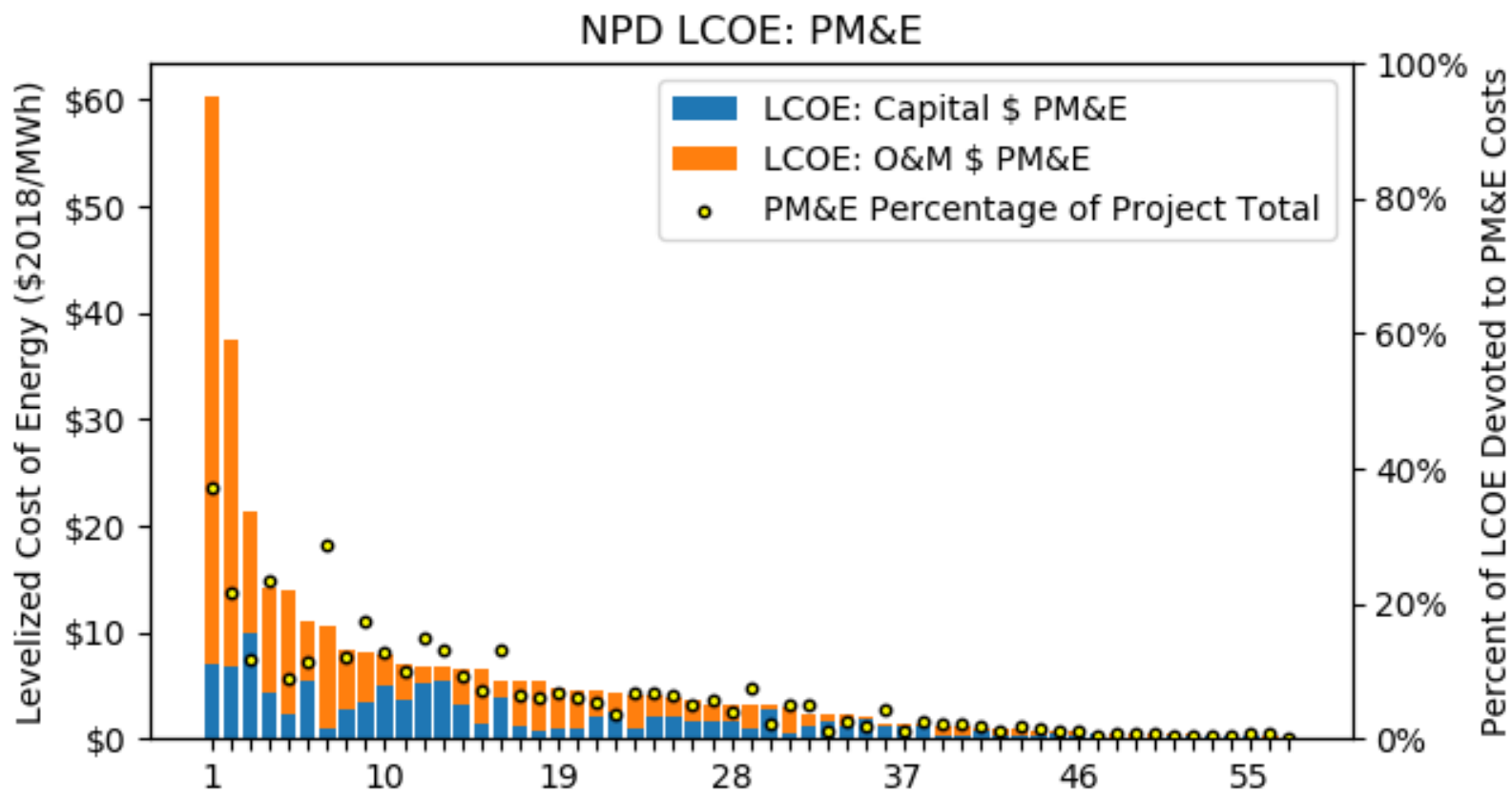

Figure 11: PM\&E LCOE Estimates for the 57 NPD projects between 2004 and 2016. The dots represent the percentage of PM\&E LCOE in Total Project LCOE. 


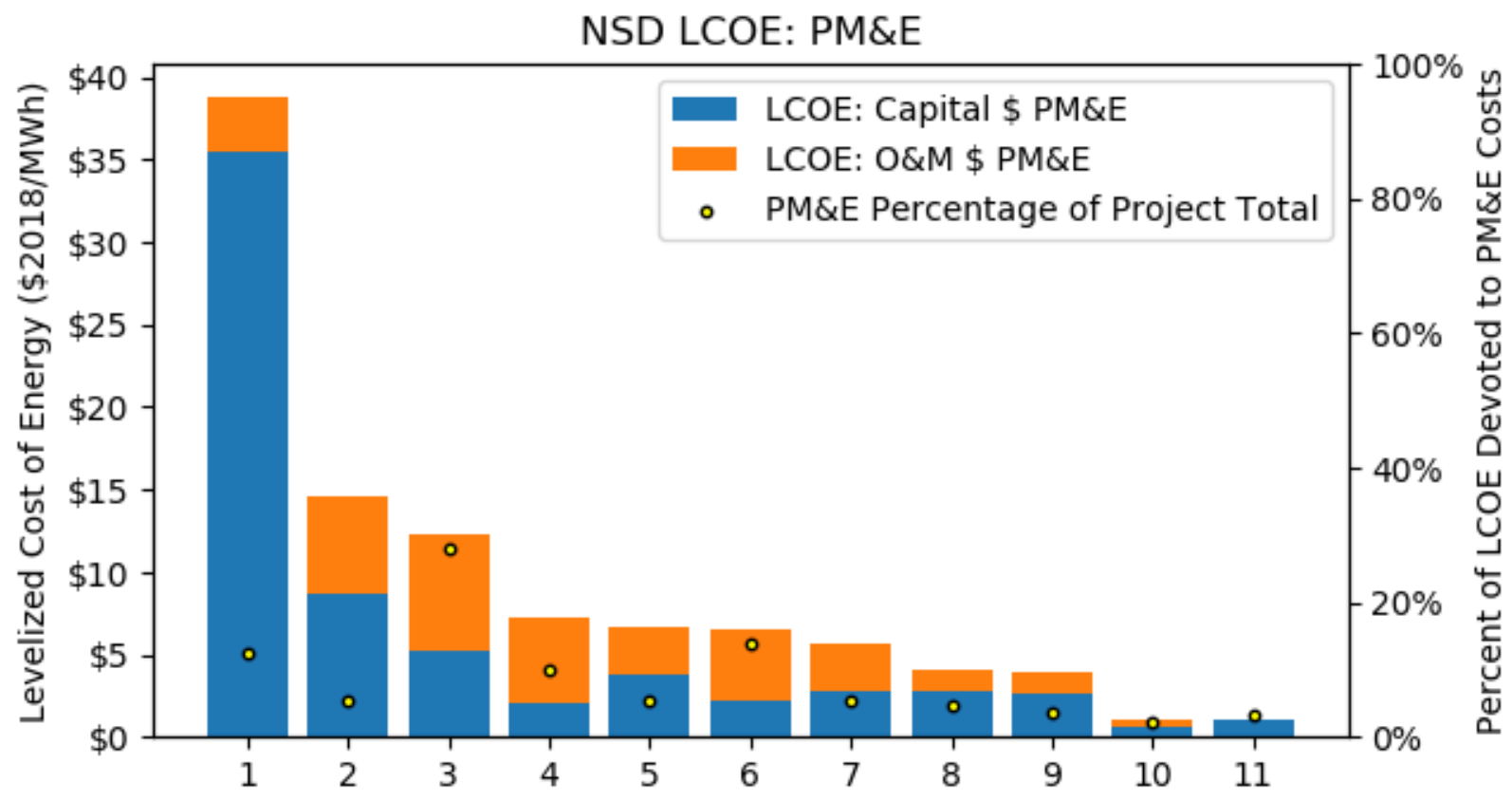

Figure 12: PM\&E LCOE Estimates for the 11 NSD projects between 2011 and 2017. The dots represent the percentage of PM\&E LCOE in Total Project LCOE.

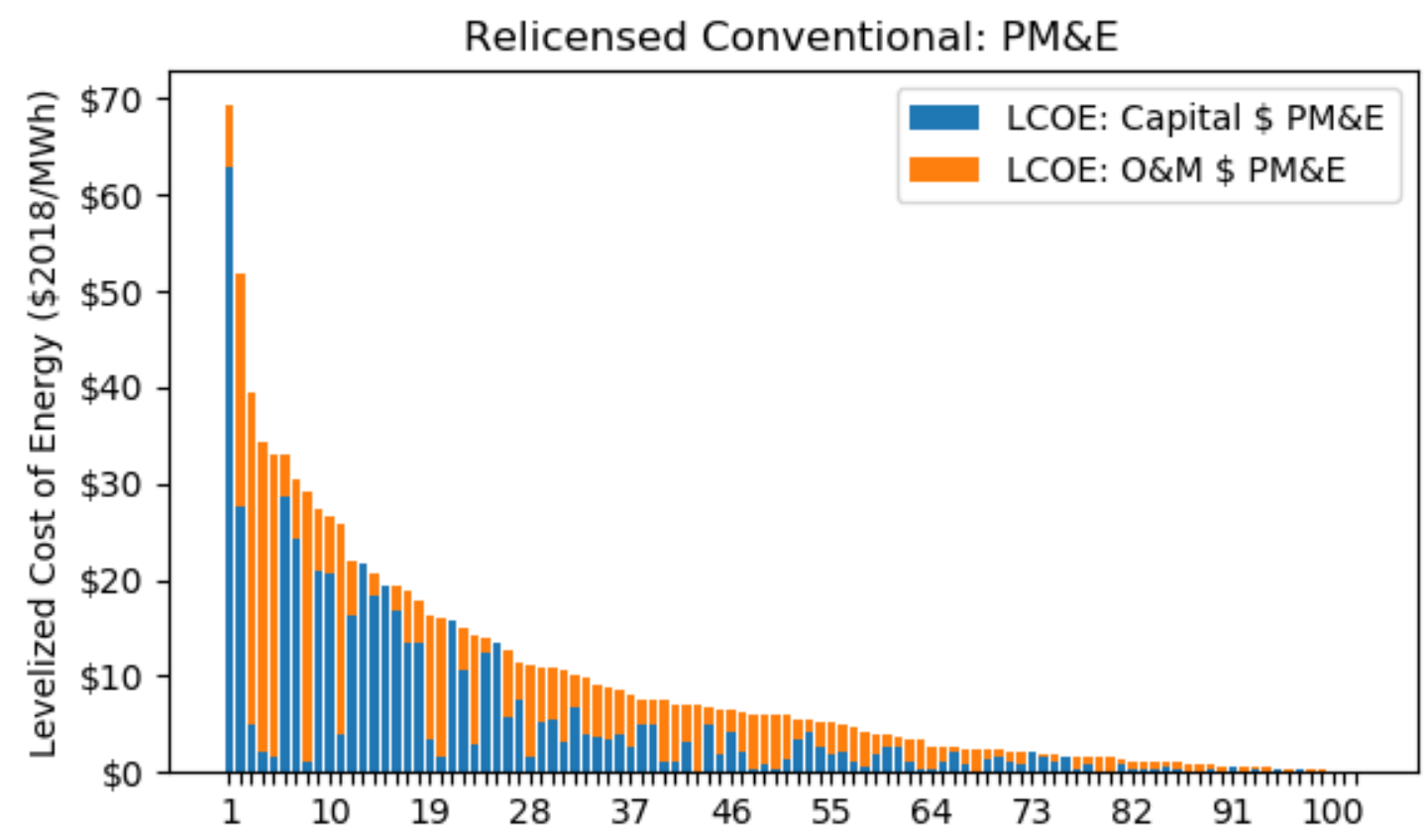

Figure 13: PM\&E LCOE Estimates for the 103 Relicensed Conventional projects between 1996 and 2017. Not enough data was available to determine the proportion of PM\&E in Total Project LCOE. 


\section{CONCLUSIONS}

Based on our analysis of the PM\&E cost data for 184 hydropower projects with license or relicense application reviews between 1996 and 2018, we observed several notable trends across and within project types. Across all project types, LCOEs are mostly below $\$ 30 / \mathrm{MWh}$, with few exceptions. Additionally, for most NPD and NSD projects, PM\&E measures typically account for 5-10\% of project total LCOE, with a handful of projects having up to $20-40 \%$. Not enough data was available to calculate percentages for RCHD. On the other hand, capital and O\&M PM\&E costs on a $\$ / \mathrm{kW}$ basis are highest for RCHD projects. These projects are being required to meet environmental standards that were not existing when they were originally licensed decades earlier. In addition, some RCHD projects in our database have small installed capacities, raising costs on a per $\mathrm{kW}$ basis, whiles other have no costs for certain PM\&E measures. The opposite holds true for PSH, where the capital and O\&M costs on a $\$ / \mathrm{kW}$ basis are generally lower even though the total PM\&E costs are quite substantial, which can be primarily attributed to having projects with large installed capacities. Additionally, NPSH projects are closed-loop, or not continuously connected to a natural water body, and hence, have fewer environmental impacts. However, RPSH projects are open-loop (continuously connected to a natural water body) so that their lower costs per $\mathrm{kW}$ are largely due to the size of the facilities. Regardless of configuration, PSH projects have the narrowest IQRs for each of the mitigation categories owing partially to the low sample sizes of each type (six for RPSH and four for NPSH). When separating PM\&E costs by mitigation category, Geologic Resources, Terrestrial Resources, Project Operations, Recreation Resources, and Aquatic Species generally have the highest median capital expenditures, with slight variations, across all project types. This potentially results from these categories being involved with the initial planning and construction stages, leading to high upfront costs related to studies, earth-moving, and physical facility components. $\mathrm{O} \& \mathrm{M}$ costs per $\mathrm{kW}$ are low across all project types signifying that O\&M is rarely a significant burden. However, Water Quality, Aquatic Species, and Other measures have the highest median O\&M costs for most project types. Generally, these categories contain measures requiring more ongoing monitoring and active mitigation than the others, and involve specific species protection, water aeration, and migration aids (i.e. migratory fish passageways).

A key takeaway from our analysis is that environmental mitigation measures can be more expensive for low capacity projects, which constitutes most of the remaining undeveloped potential in the U.S. This also applies to smaller relicensed projects depending on their age and operational history, as extensive mitigation requirements could make continuing operation uneconomical, which is not necessarily the case for larger conventional and PSH relicenses. Additionally, closed-loop PSH has the potential to avoid numerous environmental mitigation measures since there is limited connection to natural water bodies and their associated ecosystems, although total PM\&E costs can still be substantial share of initial investments due to the larger size of these project types.

Given the inconsistences in the classifications of environmental mitigation measures, the FERC application process may benefit from changes to the data collection process that could assist applicants with their license applications and researchers with interpreting the posted information. A potential change would be to specify the methods for annualizing cost estimates to allow for equal comparability across projects. Additionally, specifying a standard classification scheme for environmental mitigation categories at a greater level of detail would allow for consistent classification across projects. Data validation forms can also be used to collect relevant mitigation economic information from applicants without compelling them to severely alter their EA submission. It would be particularly useful to provide stricter definitions of the environmental mitigation measures addressed by high value (in the millions of dollars) construction items and low value administrative items that could influence the interpretation of mitigation costs. For instance, it is not readily clear how a turbine/generator replacement or an escrow account addresses adverse environmental effects. 
The findings of our analysis indicate that understanding the economics of environmental mitigation is paramount in future hydropower development. Accordingly, our EA Cost Database can be used to support efforts to quantify the costs associated with environmental mitigation for different hydropower project types. One of our planned future efforts is to use the database to produce parametric equations for estimating environmental mitigation costs of at proposed sites based on their geographic location, project type, and installed capacity, among other factors. This would complement a tool recently developed by researchers at Oak Ridge National Laboratory for predicting potential environmental mitigation requirements at proposed hydropower sites. 


\section{REFERENCES}

DeRolph, C., Schramm, M., \& Bevelhimer, M. (2016). Predicting environmental mitigation requirements for hydropower projects through the integration of biophysical and socio-political geographies. Science of the Total Environment, 566-567, 888-918. Retrieved from https://hydrowise.ornl.gov/sites/default/files/201706/Predicting_environmental_mitigation_requirements_for_hydropower_project.pdfoval_and_Mi tigation_Report.pdf

DOE (Department of Energy). (2016). Hydropower Vision: A New Chapter for America's 1st Renewable Electricity Source. Office of Energy Efficiency and Renewable Energy Wind and Water Power Technologies Office, Washington, DC http://energy.gov/eere/water/articles/hydropowervisionnew-chapter-america-s-1st-renewable-electricity-source

FERC (Federal Electricity Regulatory Commission). (2017). Hydropower Primer: A Handbook of Hydropower Basics. A staff report of the Office of Energy Projects. https://www.ferc.gov/legal/staff-reports/2017/hydropower-primer.pdf

FERC (Federal Electricity Regulatory Commission). (2019). Hydroelectric Licensing Regulations Under the America's Water Infrastructure Act of 2018. Docket No. RM19-6-000; Order No. 858. https://www.ferc.gov/whats-new/comm-meet/2019/041819/H-1.pdf

Gracey, E. O., \& Verones, F. (2016). Impacts from hydropower production on biodiversity in an LCA framework-review and recommendations. The International Journal of Life Cycle Assessment, 21(3), 412-428.

Hadjerioua, B., Wei, Y., \& Kao, S. C. (2012). An Assessment of Energy Potential at Non-Powered Dams in the United States. Prepared for the U.S. Department of Energy Wind-Water Program by Oak Ridge National Laboratory. https://www1.eere.energy.gov/water/pdfs/npd report.pdf

Hall, D., Hunt, R., Reeves, K., \& Carroll, G. (2003). Estimation of Economic Parameters of U.S. Hydropower Resources. Retrieved from https://www1.eere.energy.gov/water/pdfs/doewater00662.pdf

Kao, S., Mcmanamay, R., Stewart, K., \& et al. (2014). New Stream-reach Development: A Comprehensive Assessment of Hydropower Energy Potential in the United States. United States. Doi:10.2172/1130425. https://info.ornl.gov/sites/publications/Files/Pub46481.pdf

Massarutto, A., \& Pontoni, F. (2015). Rent seizing and environmental concerns: A parametric valuation of the Italian hydropower sector. Energy Policy, 78, 31-40. Retrieved from https://www.sciencedirect.com/science/article/pii/S0301421514006818

Meier, P., P. Blaszczyk, C. Harris, \& K. Gilbert. (2010). "Project Development: From Concept to Construction: Steps to Developing a Hydro Project.” Hydro Review, Volume 29, Issue 3.

Parish, E. S., Pracheil, B. M., McManamay, R. A., \& et al. (2019). Review of environmental metrics used across multiple sectors and geographies to evaluate the effects of hydropower development. Applied Energy, 238. 
Schramm, M. P., Bevelhimer, M. S., \& DeRolph, C. R. (2016). A synthesis of environmental and recreational mitigation requirements at hydropower projects in the United States. Environmental Science \& Policy, 61, 87-96.

Uría-Martínez, R., Johnson, M. M., \& O'Connor, P. W. (2018). 2017 Hydropower Market Report. Water Power Technologies Office, U.S. Department of Energy.

WDNR (Wisconsin Department of Natural Resources). (2017). Fish Passage at Dams Strategic Analysis. Retrieved from https://dnr.wi.gov/topic/EIA/documents/FPSA/FPDSAfinal2-5-18.pdf

Wilkinson, J., Raepple, J., Rossner, R., \& et al. (2017). Environmental Markets and Stream Barrier Removal: An Exploration of Opportunities to Restore Freshwater Connectivity Through Existing Mitigation Programs. The Nature Conservancy: Arlington, VA. Retrieved from https://www.nature.org/content/dam/tnc/nature/en/documents/2017_Stream_Barrier_Removal_an d_Mitigation_Report.pdf 


\section{APPENDIX A. DATA OUTLIERS}

\begin{tabular}{|c|c|c|c|c|c|}
\hline $\begin{array}{l}\text { FERC } \\
\text { Docket } \\
\text { Number }\end{array}$ & Project Name & $\begin{array}{l}\text { Environmental } \\
\text { Mitigation Measure }\end{array}$ & $\begin{array}{l}\text { Initial Capital } \\
\text { Cost (2018\$) }\end{array}$ & $\begin{array}{l}\text { Annual O\&M } \\
\text { Cost (2018\$) }\end{array}$ & $\begin{array}{l}\text { Reason for } \\
\text { Omission }\end{array}$ \\
\hline p-2114 & Priest Rapids & $\begin{array}{l}\text { Release increased } \\
\text { seasonal percentages of } \\
\text { mean annual flow } \\
\text { downstream of several } \\
\text { dams }\end{array}$ & 0 & $70,864,510$ & $\begin{array}{l}\text { Extremely high } \\
\text { O\&M cost }\end{array}$ \\
\hline p-2114 & Priest Rapids & $\begin{array}{l}\text { Spill at both dams for } \\
\text { downstream fish } \\
\text { passage }\end{array}$ & 0 & $18,000,000$ & $\begin{array}{l}\text { Extremely high } \\
\text { O\&M cost }\end{array}$ \\
\hline p-2114 & Priest Rapids & $\begin{array}{l}\text { Flows to protect rearing } \\
\text { Fall Chinook salmon }\end{array}$ & $46,200,000$ & $112,500,000$ & $\begin{array}{l}\text { Extremely high } \\
\text { initial capital } \\
\text { and O\&M costs }\end{array}$ \\
\hline p-2114 & Priest Rapids & $\begin{array}{l}\text { Downstream fish } \\
\text { bypass system }\end{array}$ & $26,874,403$ & 11,1241864 & $\begin{array}{l}\text { Extremely high } \\
\text { O\&M costs }\end{array}$ \\
\hline p-2146 & Coosa River & $\begin{array}{l}\text { Release increased } \\
\text { seasonal percentages of } \\
\text { mean annual flow } \\
\text { downstream of several } \\
\text { dams }\end{array}$ & 0 & $70,864,510$ & $\begin{array}{l}\text { Extremely high } \\
\text { O\&M cost }\end{array}$ \\
\hline p-2165 & Warrior River & $\begin{array}{l}\text { Implement a Wildlife } \\
\text { Management Plan }\end{array}$ & 22,952 & 0 & $\begin{array}{l}\text { FERC only } \\
\text { accepted part of } \\
\text { the measure and } \\
\text { didn't specify } \\
\text { how that } \\
\text { affected costs }\end{array}$ \\
\hline p-2165 & Warrior River & $\begin{array}{l}\text { Implement the Forest } \\
\text { Service Agreement }\end{array}$ & 323,708 & 40,365 & $\begin{array}{l}\text { FERC only } \\
\text { accepted part of } \\
\text { the measure and } \\
\text { didn't specify } \\
\text { how that } \\
\text { affected costs }\end{array}$ \\
\hline p-2165 & Warrior River & $\begin{array}{l}\text { Implement the Smith } \\
\text { Tailrace Enhancement } \\
\text { Proposal }\end{array}$ & 2,625 & 35,905 & $\begin{array}{l}\text { FERC only } \\
\text { accepted part of } \\
\text { the measure and } \\
\text { didn't specify } \\
\text { how that } \\
\text { affected costs }\end{array}$ \\
\hline p-2165 & Warrior River & $\begin{array}{l}\text { Supplement the tailrace } \\
\text { flow during periods of } \\
\text { non-generation }\end{array}$ & 55,675 & 116,805 & $\begin{array}{l}\text { FERC only } \\
\text { accepted part of } \\
\text { the measure and } \\
\text { didn't specify }\end{array}$ \\
\hline
\end{tabular}




\begin{tabular}{|c|c|c|c|c|c|}
\hline & & & & & $\begin{array}{l}\text { how that } \\
\text { affected costs }\end{array}$ \\
\hline p-2197 & Yadkin & $\begin{array}{l}\text { Complete the removal } \\
\text { of the High Rock Lake } \\
\text { sediment delta and } \\
\text { conduct annual } \\
\text { sediment dredging }\end{array}$ & $600,000,000$ & $7,000,000$ & $\begin{array}{l}\text { Extremely high } \\
\text { initial capital } \\
\text { cost }\end{array}$ \\
\hline p-2197 & Yadkin & $\begin{array}{l}\text { Upgrade powerhouse } \\
\text { units }\end{array}$ & $110,145,451$ & $5,461,000$ & $\begin{array}{l}\text { Extremely high } \\
\text { initial capital } \\
\text { cost }\end{array}$ \\
\hline p-2210 & Smith Mountain & $\begin{array}{l}\text { Develop a plan to } \\
\text { address erosion and } \\
\text { sedimentation that } \\
\text { includes multiple } \\
\text { criteria }\end{array}$ & $47,500,000$ & 120,000 & $\begin{array}{l}\text { Extremely high } \\
\text { initial capital } \\
\text { cost }\end{array}$ \\
\hline $\mathrm{p}-2351$ & Cabin Creek & $\begin{array}{l}\text { Upgrade pump-turbine } \\
\text { units and increase } \\
\text { storage capacity of } \\
\text { upper reservoir }\end{array}$ & $73,489,830$ & 0 & $\begin{array}{l}\text { Extremely high } \\
\text { initial capital } \\
\text { cost }\end{array}$ \\
\hline p-11858 & Lake Elsinore & $\begin{array}{l}\text { Construct underground } \\
\text { powerline following } \\
\text { licensee's proposed } \\
\text { transmission alignment }\end{array}$ & $60,680,100$ & 0 & $\begin{array}{l}\text { Extremely high } \\
\text { initial capital } \\
\text { cost }\end{array}$ \\
\hline p-11858 & Lake Elsinore & $\begin{array}{l}\text { Construct underground } \\
\text { powerline following } \\
\text { staff's alternative } \\
\text { transmission alignment }\end{array}$ & $48,999,800$ & 0 & $\begin{array}{l}\text { Extremely high } \\
\text { initial capital } \\
\text { cost }\end{array}$ \\
\hline p-11945 & Dorena & $\begin{array}{l}\text { Construct upstream fish } \\
\text { passage facilities }\end{array}$ & $27,000,000$ & 100,000 & $\begin{array}{l}\text { Extremely high } \\
\text { initial capital } \\
\text { cost }\end{array}$ \\
\hline p-13123 & Eagle Mountain & $\begin{array}{l}\text { Install a reserve } \\
\text { osmosis desalination } \\
\text { facility and brine } \\
\text { disposal lagoon }\end{array}$ & $45,400,000$ & 715,000 & $\begin{array}{l}\text { Extremely high } \\
\text { initial capital } \\
\text { cost }\end{array}$ \\
\hline p-13318 & Swan Lake & $\begin{array}{l}\text { Bury the entire } \\
\text { transmission line }\end{array}$ & $120,000,000$ & 65,000 & $\begin{array}{l}\text { Extremely high } \\
\text { initial capital } \\
\text { cost }\end{array}$ \\
\hline
\end{tabular}

